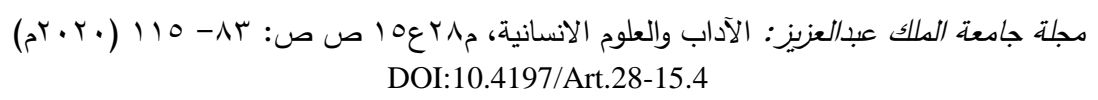

موقع التخييل عند السجلماسي

$$
\text { قد أستاذة الأدب والنقد الحدمد عبد الله أبو سالم اللغساعد العربية- كلية العلوم الإنسانية }
$$

مستخلص. يعد أبو محمد السجلماسي الذي عاش بالمغرب أواخر القرن السابع الهجري(Vه) من أعظم رواد

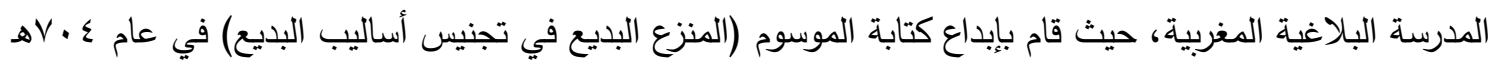

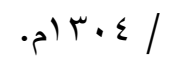

و (المنزع البديع) كتاب جاد مبتكر في النقد والبلاغة من وجهه نظر فلسفية ومنطقية، وظف فيه السجلماسي العقل

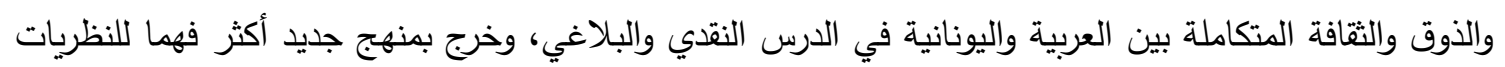
الأرسطية في النقد والبلاغة.

وقد كان هدف الدراسة من ذلك إظهار الملامح المميزة لكتاب المنزع من خلال استعراض أهم ما جاء بهاء من مباحث صنفها السجلماسي تحت علم البيان - ونخص بالذكر ما يتعلق منها بالشعر والشعرية والعناصر الرئيسة

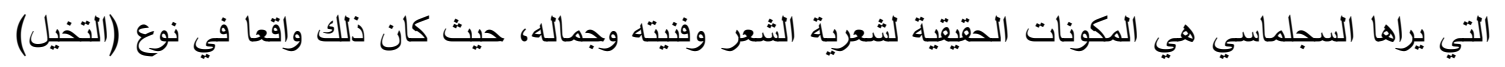

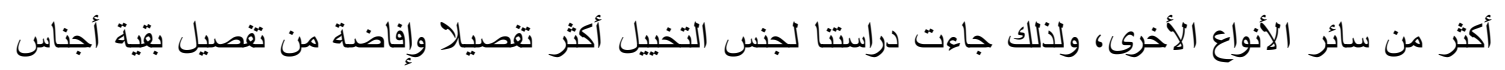

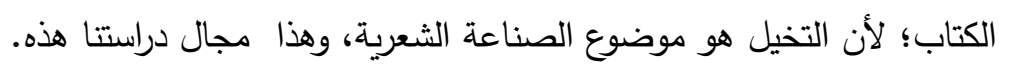

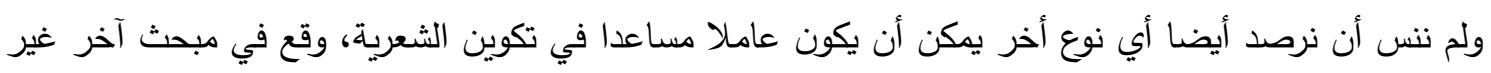

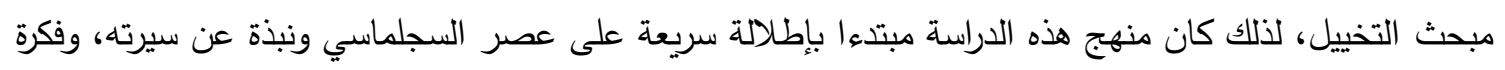

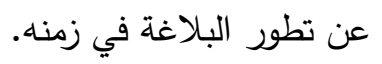


ثم عرضنا في المبحث الثاني بعض ملامح الكتاب وجديد السجلماسي الذي ميزه به، قبل أن نصل إلى المبحث

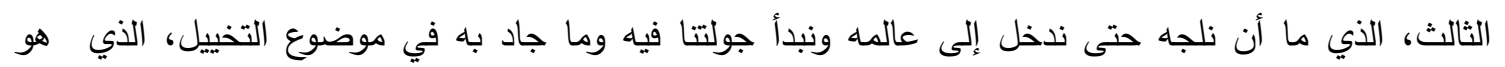
موضوعنا الأساسي لهذه الدراسة.

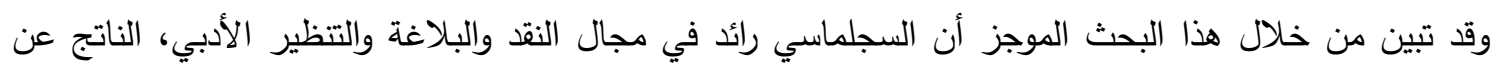

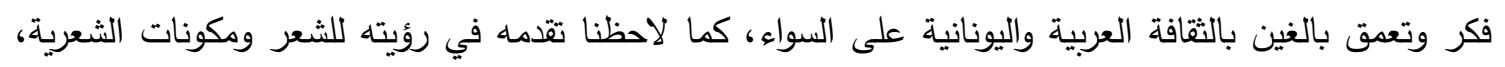

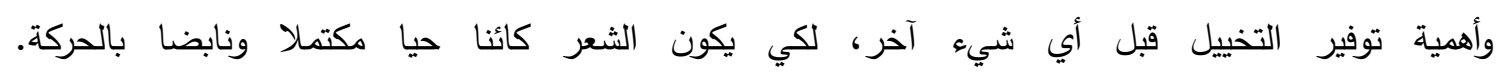

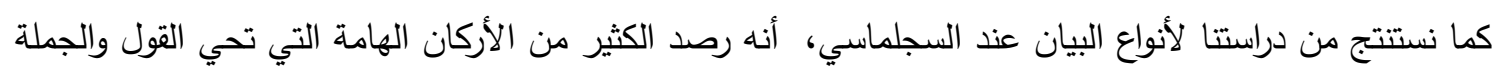

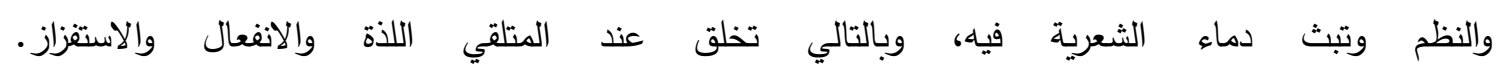
تقديم أول: ظهرت في نهايات القرن السابع الهجري ومشارف القرن الثامن، مدرسة بلاغية عربية مغربية كانت أكثر اطلاعا

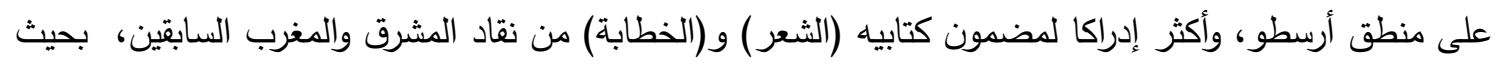

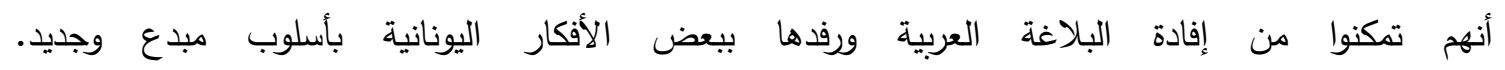

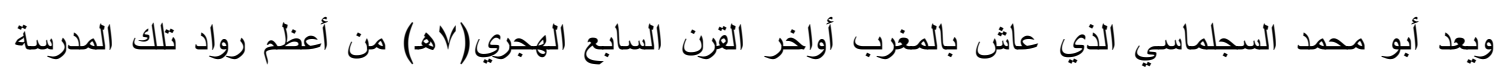

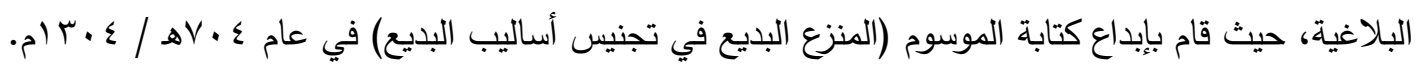

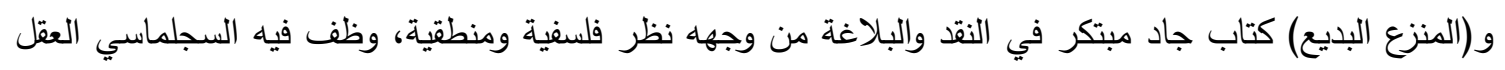

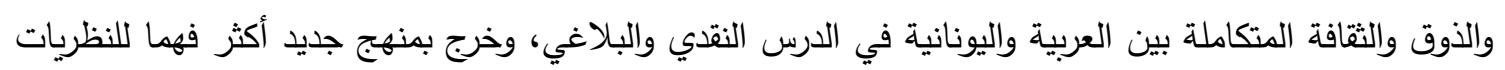

$$
\text { الأرسطية في النقد والبلاغة (1) }
$$

وكان السجماسي في كتابه يسعى "لوضع قوانين كلية لعملية الصياغة الأدبية، ويطرح مفهومه للشعر :ماهيته

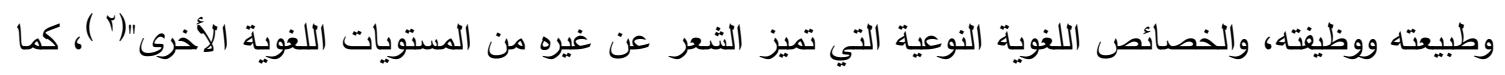

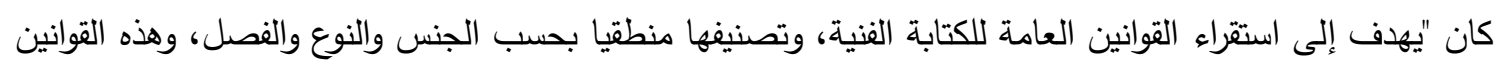

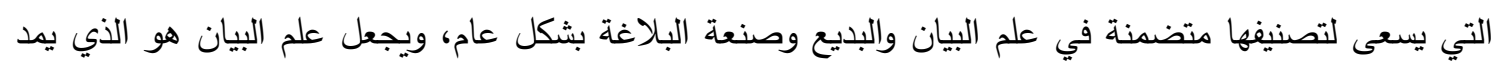

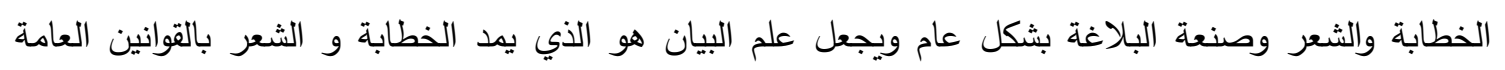

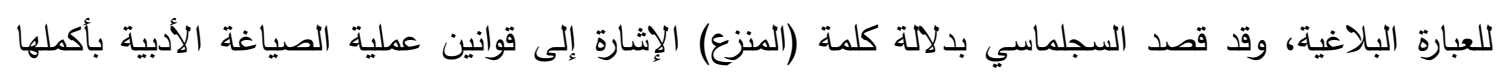

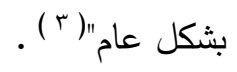

واليونانية، لتضيف جوهرة لامعة فريدة إلى عقد

\section{المقدمة}

لقد جاءت هذه الدراسة محاولة متواضعة للتجول البلاغة العربية وبيانها. وقد كان هدف الدراسة من ذلك إظهار الملامح

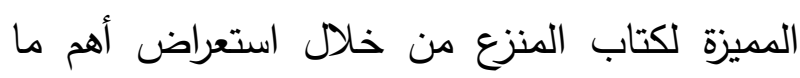

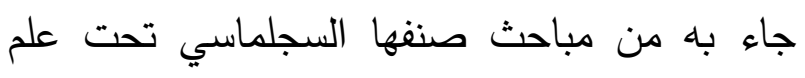
البيان - ونخص بالذكر ما يتعلق منها بالشعر الجاد في غابات كتاب المنزع المتشكلة من أشجار بليغة، تتفرع عنها عشرات الثمار البيانية الناضجة

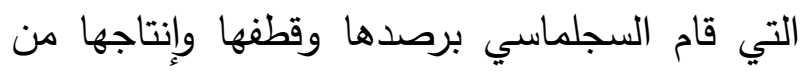
جديد، بأسلوب هو مزيج من الثقافتين العربية 
ليلى التميمي (التخييل عند السجلماسي في كتابه المنزع البديع)، وغيرها.

وأخيرا أرجو أن أكون قد وفقت بقدر جهدي المتواضع في خوض غمار كتاب عملاق! فالدراسة حاولت أن تعبد الطريق حتى ولو بحجر واحد.

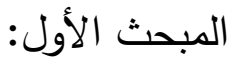

\section{ا ـ إطلالة على العصر:}

عاش السجلماسي في عصر الدولة المرينية بالمغرب خلال القرن الثامن الهجري، في الوقت الذي كان يسيطر المرينيون فيه على منطقة المغرب العربي، وتفرغوا للبناء الحضاري والاقتصادي والفكري، وكان العهد عهد ازدهار في ألوان الفن الإسلامي وتطور الثقافة باختلاف تياراتها ومذاهبها .

كما شهد هذا العصر تطورا ملحوظا في مختلف العلوم النظرية والإنسانية والأدبية،حيث تكونت خصائص المدرسة الغربية الفلسفية من خلال تلاحم المصادر الأساسية اليونانية والشرقية بالجذور المحلية المغربية، وبرز المفكرون الكبار أصحاب الوجه الخاص بين مفكري العالم مثل : ابن خلدون وابن رشد، ومن بعدهم السجلماسي، والأديب حازم القرطاجني، والمفكر الأديب ابن البناء المراكشي . كما جاء تطور الأدب والشعر تبعا لتطور العقلية المغربية وانسجام القمة مع القاعدة في الدولة المرينية، التي أحب ملوكها الأدب ورجاله، وتدارسوا الشعر مع الشعراء والدارسين (ء).
والشعرية والعناصر الرئيسة التي يراها السجلماسي هي المكونات الحقيقية لشعرية الشعر وفنيته وجماله، حيث كان ذلك واقعا في نوع (التخيل) أكثر من سائر الأنواع الأخرى، ولذلك جاءت دراستنا لجنس التخييل أكثر تفصيلا وإفاضة من تفصيل بقية أجناس الكتاب؛ لأن التخييل هو موضوع الصناعة الشعرية، وهذا مجال دراستنا هذه. ولم ننس أن نرصد أيضا أي نوع أخر يمكن أن يكون عاملا مساعدا في تكوين الثعرية،، وقع في مبحث آخر غير مبحث التخييل، لذلك كان منهج هذه الدراسة مبتدءا بإطلالة سريعة على عصر السجماسي ونبذة عن سيرته، وفكرة عن تطور

$$
\text { البلاغة في زمنه . - البه }
$$

ثم عرضنا في المبحث الثاني بعض ملامح الكتاب وجديد السجلماسي الذي ميزه به، قبل أن نصل إلى المبحث الثالث، الذي ما أن نلجه حتى ندخل إلى عالمه ونبدأ جولتنا فيه وما جاد به في موضوع التخييل، الذي هو موضوعنا الأساسي لهذه الدراسة. وقد أفدت من دراسات عدة تحدثت عن التخييل والسجلماسي، منها على سبيل المثال لا الحصر: دراسة علال الغازي (تطور مصطلح التخييل في نظرية النقد الأدبي عند السجلماسي)، ودراسة ألفت الروبي (مفهوم الشعر عند السجماسي)، ودراسة سعاد المانع (مفهوم مصطلح (المجاز) عند السجماسي في علاقته بمصطلح (التخييل)، ودراسة 
التي اتثق النقاد العرب على ذكرها كأمثلة من الثعر

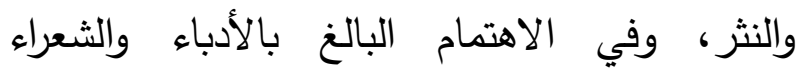
والدارسين من النقاد والفلاسفة سواء في اختياراته الذكية للصور، أو في الفهم العميق لما خفي من ون أسرار تلك الصور ودلالتها الفنية والفكرية، إضافة إلى ولعه بإيراد الآراء النقدية والفلسفية وتحليلها ومناقشتها، واتخاذ الموقف الذي يراه صالحا منها،(لا فرق بين قدامه وابن جني وابن رشيق والفارابي وأرسطو).

ومن جوانب ثقافة السجلماسي، أنه علم من أعلام النقد والبلاغة؛ فقد تميز بمنهجه العلمي الذي انفرد به عن غيره بما حمل من عناصر الخلق والتجديد، حيث توضح ذلك مكتبته النقدية والفلسفية والمنطقية

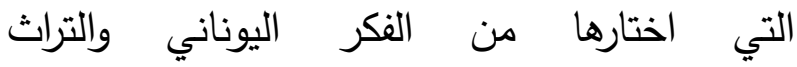
الأدبي،وأخضع مباحث كتابه لمنهاج موضوعي من لمني

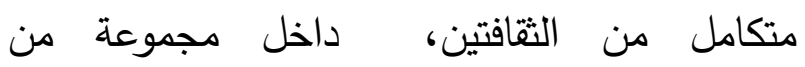
المصطلحات والمفاهيم الفلسفية التحليل، والمنطقية التقسيم، والبلاغية الروح، والنقدية التنظير والتطبيق؛ فأخرج الموضوع النقدي والبلاغي من فوضى التحديد والتحليل وفقر المصطلح إلى وضعه في إطار العلم

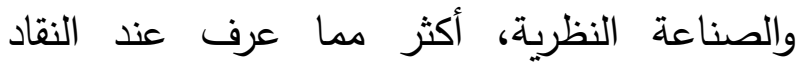
العرب، وكانت له مع أرسطو جولات كبيرة( ) . إضافة لما سبق، فإن السجلماسي يعد لغويا ونحويا وعروضيا،وواضع علم المصطلحات؛ فمن ناحية لفية اللغة ابتعد عن التفسير الجاف وتجاوزه إلى إدراج معنى الكلمة في السياق، وفي بحثه عن معنى الكلمة r l السجلماسي - سيرة سريعة: ولد أبو محمد القاسم بن محمد بن عبد العزيز الأنصاري السجلماسي في مدينة "سجلماسة" المغربية ونشأ فيها ثم رحل إلى فاس للأخذ عن علمائها والتدريس بها، وهناك أملى على تلاميذه كتابه

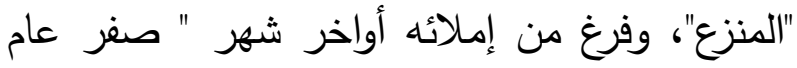

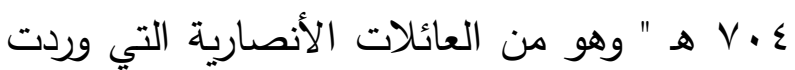
على المغرب في فترات تاريخية(ه ). والسجلماسي يمتلك ثقافة شاملة في أكثر من حقل فئل علمي ومعرفي، وله من كل علم نصيب، ومتبحر في الثقافتين اليونانية والعربية والفلسفة الإسلامية، وشخصيته كفيلسوف منطقي جانب من شموليه ثثافته، وكتاب المنزع شاهد على ذلك في أسلوبه ومنهاجه المعتمد على المصطلحات والمفاهيم النظرية قبل مناقشتها عند التطبيق • وهو أديب متفلسف، بمعنى أنه مفكر في التحليل النظري، أديب في التحليل الأدبي، ويظهر نبوغه في التحليل الأدبي في دراسته لبعض الصور والثواهد

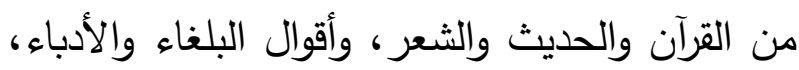
حيث كان يطبق ذلك على مصطلحات كتابه (المنزع) ، مستعينا ببعض المصطلحات المعروفة في الخطابة والثعر على إبراز القيم الجمالية، مثل : النفس والروح والصورة والخيال والانفعال..، وغير الترال التئ ذلك من الكلمات التي يدخل استعمالها عنده في البحث عن العلاقة بين التحليل النظري والتطبيق، وكما انفرد السجماسي الأديب بايراد شواهد غير لئري 
r ـ التقدم النقدي والبلاغي في زمنه: تطور الأدب العربي ونقده قبل السجلماسي، حيث بلغ أوجه في القرن الرابع الهجري بعد أن نضجت

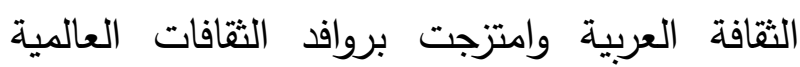
وخصوصا الفكر اليوناني، وقد قامت معركة بين

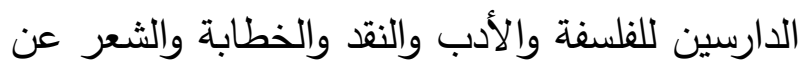
مدى ما أحدثه الفكر اليوناني من أثر في النقدابة والن

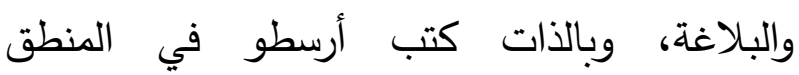
والخطابة والثعر ، وقد تمثلت المعركة في اتجاهين

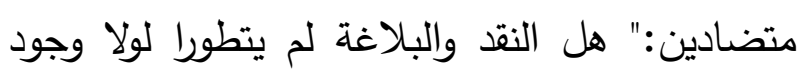

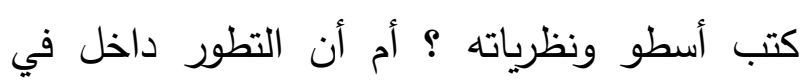
إطار الروافد التي تسهم في البناء الثقافي للأمم؟ وأن

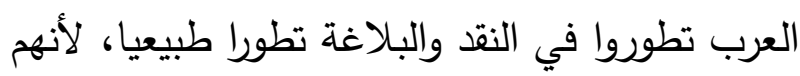

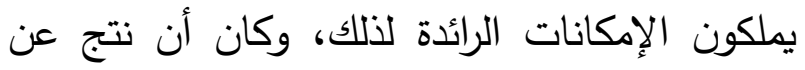

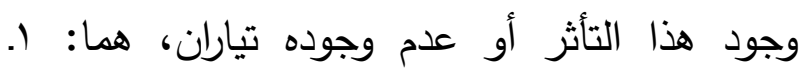
التيار الأول: يرى الثقافة اليونانية لم تؤثر في النقد واتدان والبلاغة العربية، بمعنى أن التطور الذي حصل كان النيان عربي الروح والأسلوب والمضمون والمنهاج المنهاج

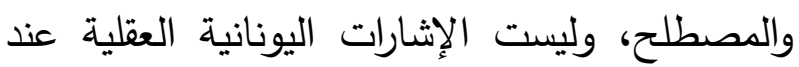
بعض النقاد العرب مثل (قدامه) إلا رافدا من روافد ثثافة النقاد العامة، لا يتجاوز السطح إلى الجوهر . r ـ التيار الثاني: يرى أن الثقافة اليونانية أحدثت أثرا

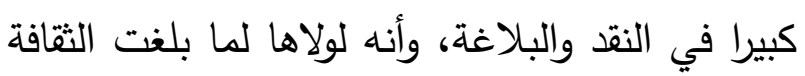

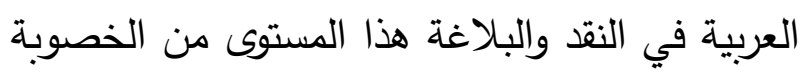
عبر عصورها، ودليلهم على ذلك أن النقد والبلاغة العربيين قد حملا خصائص لم تكن موجودة قبل وليل
عند الجمهور، يعود للتقيب عن أصلها اللغوي، ويقف عندها باختصار وتركيز حتى تصبح مهيأة لقبول مقاييس المصطلح، حيث قدم للغة إمكانات هائلة، كما كانت لله شخصيته المستقلة في المجال النحوي، شخصية واضحة بين أعلام النحو كسيبويه وابن جني والفارسي والأخفش، من خلال تحليله وتعليله للإشكالات النحوية في وضعها بين الإعراب والمعنى الذي يفرضه السياق، كما كان واثقا عند مناقشته قضية الشعر والوزن .

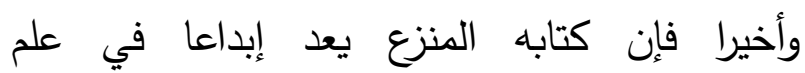
المصطلحات، يجعل السجماسي ينفرد بمنهاج جديد

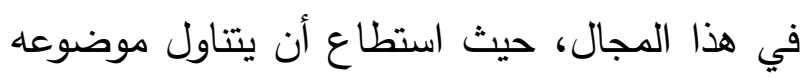

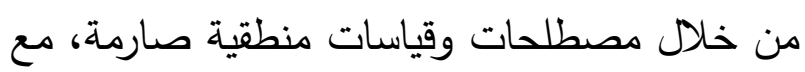
مسحة أدبية ومنهاج علمي يخضع للتصميم الجيد الذي وضعه لكتابه، كل ذلك في انسجام عضوي واتحاد منهجي بالثقافة النقدية والبلاغية العربية، وفي تخطيط ذكي ينطلق من الكليات بوصفها أجناسا عالية، قسم إليها مباحث (المنزع) تتفرع عنها تتازليا

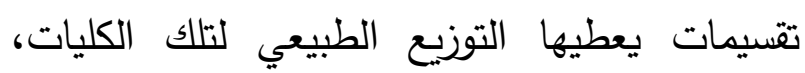
ونظام المقارنة بين النقد والبلاغة عند العرب، وما ينسجم معها في الفكر اليوناني بعد أن وظف منطقه

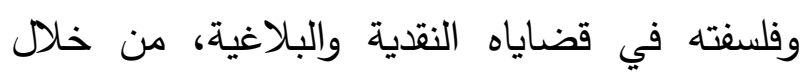
نورين:التحديد النظري للقضية،ثم التطبيق من التراث

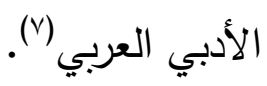


عصر الترجمة، سواء في تطور المصطلح أوفي (المقدمة) والرحالة المغربي (ابن رشيد السبتي) في المنهاج أو في القضايا التي طرحت طرحا جديدا( (^). (رحلته الموسوعية) ( '"). ويعد الثاعر الأديب (حازم القرطاجني ) المتوفى المبحث الثاني: على مشارف المنزع:

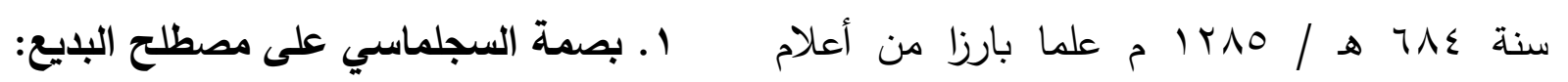
الاإتجاه اليوناني، "وهو أول من أدخل نظريات جعل السجلماسي للبديع جنسا خاصا ناقثه فلسفيا أرسطو وتعرض لتطبيقها في كتب البلاغة العربية وتطبيقا عمليا حتى حقق نقلة نوعية في مفهومه، الخالصة، وذلك في كتابه (منهاج البلغاء وسراج وأوقف انتماء هذا الدصطلح مرة لمفهوم (البيان)، الأدباء)، حيث عاصر حازم السجلماسي معاصرة ومرة لففهوم (البلاغة والفصاحة)، أو (البديع) أحيانا

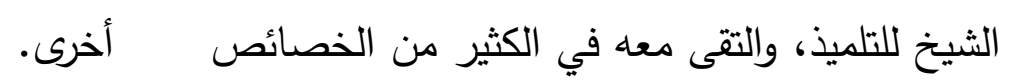

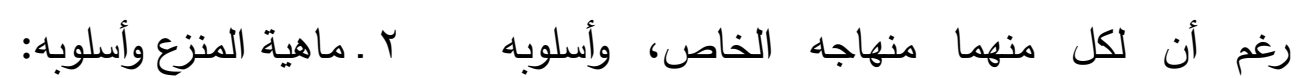
يبين السجلماسي هدفه من وضع كتابه المنزع قائلا:

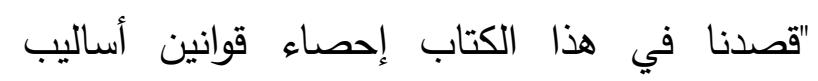
النظوم المشتملة عليها الصناعة الشعرية الموضوعة فئاء لعلم البيان وأساليب البديع،وتجنيسها في التصنيف، النياء وترتيب أجزاء الصناعة في التأليف على جهة الجنس ولنساب

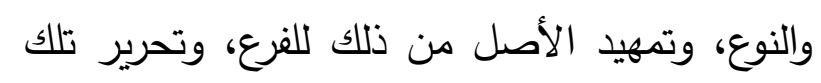

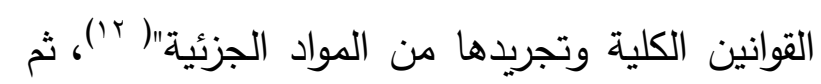

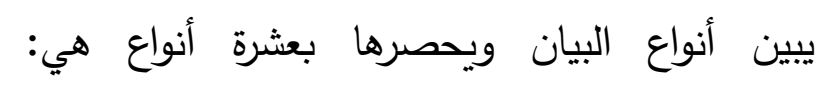

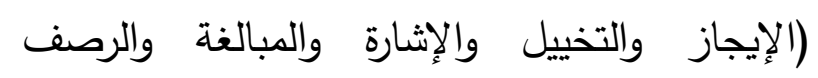

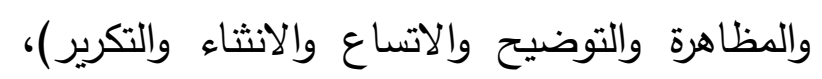

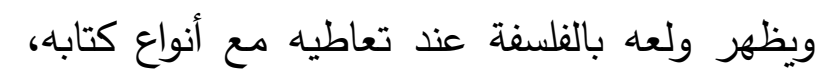

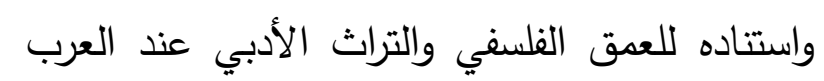

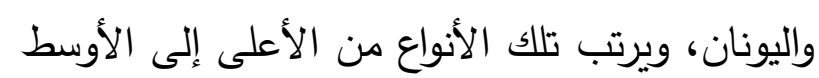

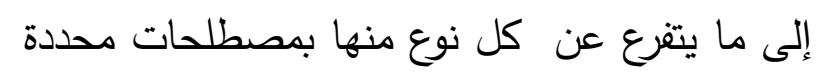
ودقيقة، وقد منهج السجماسي كتابه كالتالي (r'):

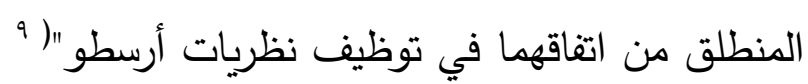
)، حيث تعرض حازم لكثير من القضايا النقدية

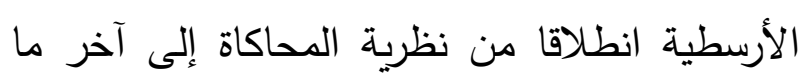
أمكن تطبيقه على البلاغة العربية .

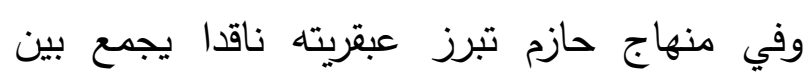

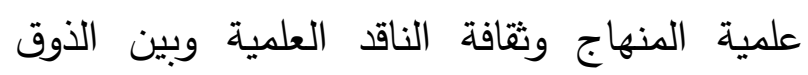
الأدبي؛ فاجتمعت في شخصيته عناصر الثقافة ولثافة

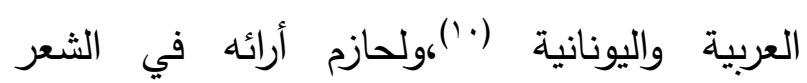
والمتلقي، قد تطرقت لها الدراسة عند المقارنة بينه وبين السجلماسي في الصفحات القادمة .

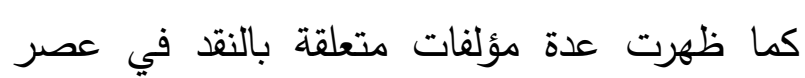

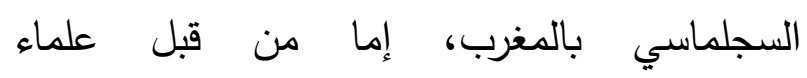
متخصصين مثل ازم في(منهاج البلغاء)، والسجلماسي في (المنزع)، وابن البناء في (الروض المريع)، أو من قبل علماء تعرضوا للنقد والبلاغة في المئي

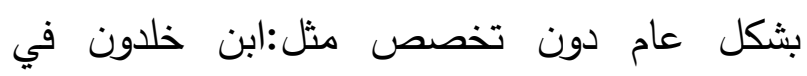


r ـ لغة السجلماسي وتطويره للمصطلحات:

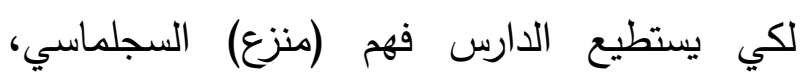
والوقوف على الثورة التنظيرية التي أحدثها بوضع منهج جديد لصناعة البديع في إطار علم البيان، وسبقه للوضع العلمي والمنهجي الفريد للنقد الأدبي في إطار قانون جديد، لا بد من تتبع تطور

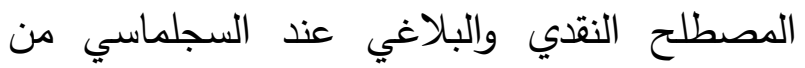

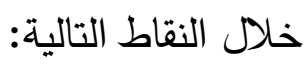
1 . المصطلح لغة واستعمالا: حيث وقف السجلماسي عند الكلمة بالمفهوم اللغوي واستعمالها الشائع عند الجمهور، ومثال ذلك قول السجلماسي

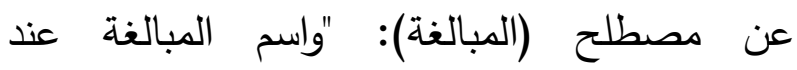
الجمهور هو مثال أول لقولهم: بالغ في الأمر يبالغ

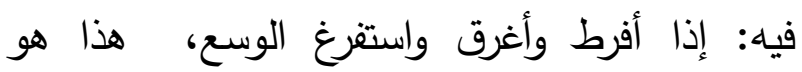

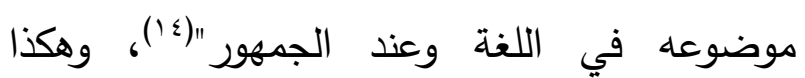
بالنسبة للمصطلحات كلها، يعرض للناحية اللغوية.

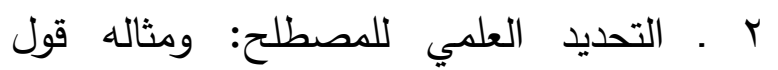
السجلماسي عن (الإيجاز): "وهو منقول إلى هذا الجنس من علم البيان على سبيل نقل الاسم من المعنى الجمهوري إلى المعنى الناشئ في الصناعة لهن الحادث فيها، وسبيل النقل بأن يكون المعنى المنقول

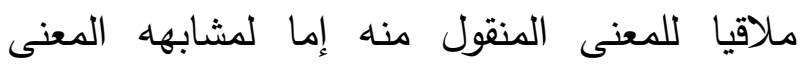
الصناعي للمعنى الجمهوري، مثل الزمام المستعمل

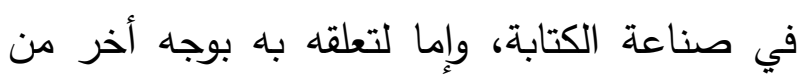
وجوه التعلق، مثل أن يسمى الثيء باسم فاعله عند

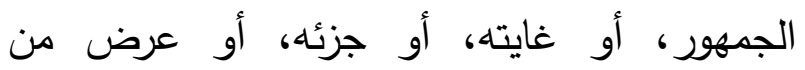

1 ـ التمهيد: حيث عرض فيه لأهمية البيان في فهم أسرار القرآن وإعجازه. r . تحديد موضوع الكتاب من خلال مباحثه العشرة. ץ ـ تتبع كل جنس ورصد تفريعاته الاصطلاحية. ع. . تحديد المصطلح من جانبه اللغوي واستعماله عند الجمهور، ثم مفهومه الاصطلاحي وطرح آراء العرب واليونان مناقشا ومعللا. 0

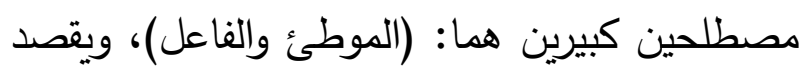
بالموطئ: المعنى أو القاسم المشترك الذي يضم لهم التفريعات اللاحقة المتولدة مباشرة، وذلك مقدمة عامة على إيجازها للفاعل، ويقصد بالفاعل: القانون العلمي النظري العام الذي يمثل القاسم المشترك بين المصطلحات التي تلتحم في وضعها الفلسفي المنطقي بدلالاتها النقدية والبلاغية وفق نظام بنيوي لغوي محدد. 7 ـ الانتقال من الكلي العام (المقدمة/الموطئ) إلى الكلي الخاص (القانون)، وقد اعتمد على شخصيته وثقافته في التخطيط لفلسفة نقدية وبلاغية، مستعينا بآراء النحاة والنقاد، والفلاسفة والمناطقة من مفكري

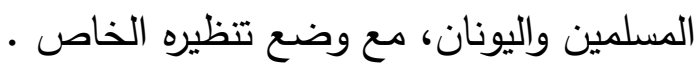
V • إيراد الصور التطبيقية ليستخرج من مناقشتها عناصر التقابل مع ما حدده في تتظير المصطلح، وذلك بعد تحليله النظري لمعطيات الفاعل وبديهياته المتجسدة في المصطلحات التي تحمل كل واحدة منها التنظير المنهجي نفسه، الموطئ ثم الفاعل. 
أعراضه، وجهة الالتقاء هنا:المشابهة . إذ في كل يناقشها نظريا وتطبيقا، ولذلك يتميز استخدام

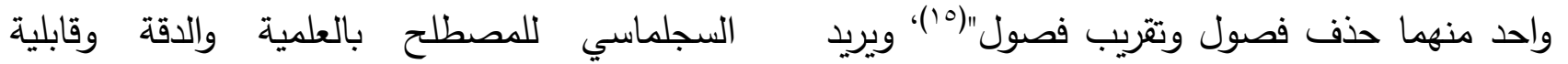
من تحديده ذلك أن يرسخ الأرضية أو القاعدة التي الاحتمال للمعاني المتعددة ضمن النوع البياني التابع

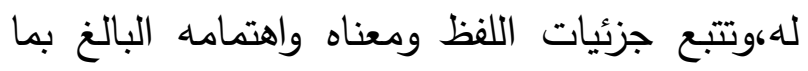

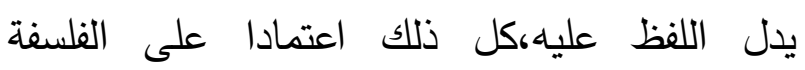

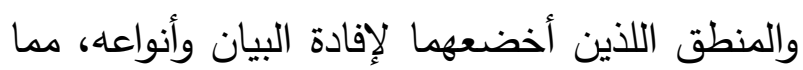
يثبت أنه كان متميزا بأسلوبه دون تقليد لأحد.

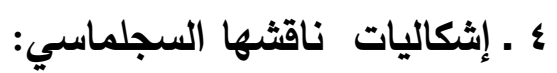
1. إشكالية الشعر بين المفهوم والخطابة: في رؤيته للشعر"أعاد السجماسي تعريف الثعر إلى أرسطو ومن شرحه من العرب، وأضفى عليه صورته الناضجة المتكاملة"( (1)، ويرى أن مفهوم الثعر لم لم يكن قد ترسخ بعد عند "أصحاب علم البيان ومتأدبي العرب، بسبب اختلاطه بالأقاويل الخطبية، وعدم

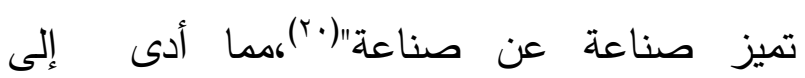
الالتباس وعدم الوضوح.

ويؤكد السجلماسي تحليل معنى "(القول المخيل) كضرورة حتمية لإعانة الأديب على التمكن من لمنيل صناعتة، وعلاقة النفس بالخلق الفني من حيث الإدئ

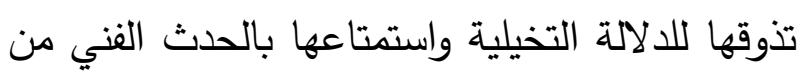
عدمه، ويرى أن الثعر وحيه التخييل متجاوزا فكرة

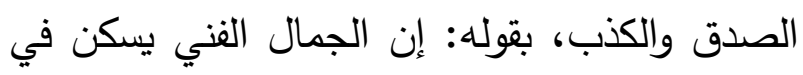
القول المستفز المتيقن كذبه والمركب من مقدمات مخترعة، أما الأسلوب الخطابي فيعطيه مكانا ضيئلا

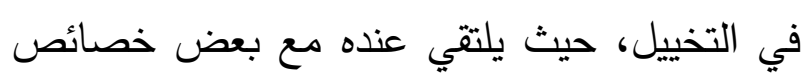

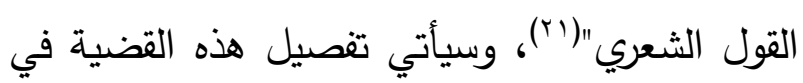


الصفحات القادمة من هذه الدراسة عند تتاولنا لجنس والاسترسال،والاتحاد العضوي بين اللفظ والمعنى مع إيراده الثواهد على ذلك من القرآن الكريم والشعر لين

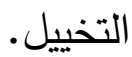

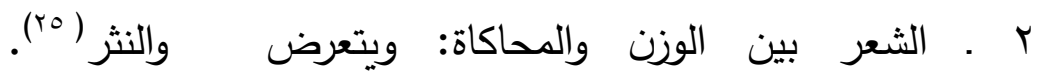

ع قضية الدلالة: قام السجلماسي بتحديد (الدلالة)فلسفيا ونقديا، وربطها بالصور استخلاصا للقضية التي يتطلبها السياق، ثم ينتقل بعد مثل هذا، ولنال

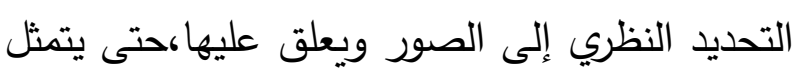
البعد الدلالي المطلوب(r؟r). ه ـ مقاييس الأسلوب الجيد: ومن القضايا التي عالجها السجلماسي قضية الأسلوب الجيد في الأدب، ويرى أنه ذلك الأسلوب الذي يعتمد على النى الفلسفة والمنطق معا دون أن يقع تحت سيطرتهما، ويشترط توفر خمسة مقاييس في البيان الجيد هي: فصاحة الألفاظ، وجزالتها، وأسهلها نطقا، وأحسنها

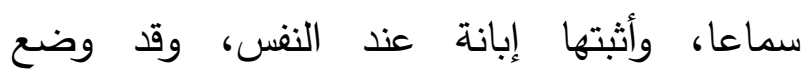
السجلماسي هذه المقاييس في نوع (البيان) لأنه يرى أن هذا العلم هو المظلة التي تستظل بها علوه البلاغة كلها. (rV)

7 ـ ـ علاقة الفن بالنفس: يرى السجلماسي أن العملية

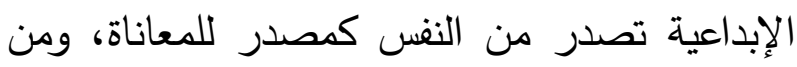
الفكر كمقوم للصناعة في تثبيت حدود العمل، فعن النفس تصدر الوحدة الفنية وإليها تعود لاستيعابها

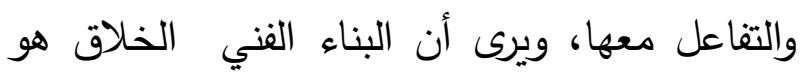
الذي يحمل في نفسه دلالة التأثير بالأسلوب والتركيب والتخييل والمحاكاة وما بينهما من جهة،
السجلماسي في هذه القضية لمصطلح (التصدير) الذي يعني: "رد أعجاز الكلام إلى صدوره، ويناقش علماء البيان والبلاغة الذي يحصرون هذا الأسلوب من التراكيب بالقول الثعري فقط، ويقع في القوافي فحسب، ولذلك فإنهم يبعدونه عن القرآن الكريم وأي قول غير شعري"(r(r)، ويثبت السجلماسي أن رأيهح

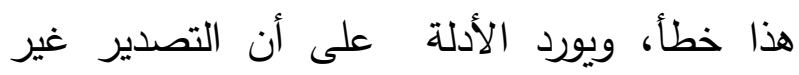
مقصور على الشعر والقوافي فقط، ويقول مثلا: (فلان سريع إلى الشر وليس إلى الخير سريع، وفلان

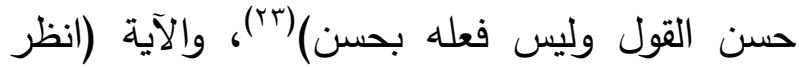
كيف فضلنا بعضهم على بعض، وللآخرة أكبر

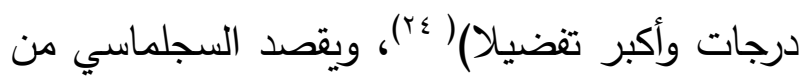

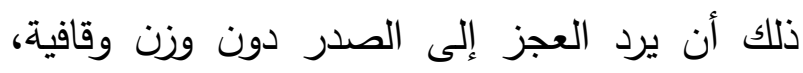

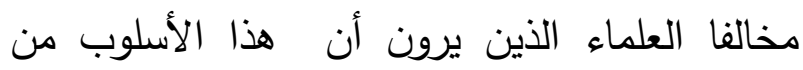

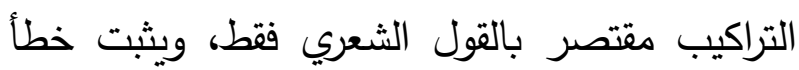
رأيهر هذا بالمثالين السابقين، وأن التصدير يقع في ولئي

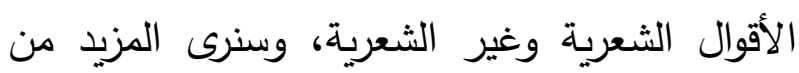
التوضيح حول التصدير عند استعراضنا لمفهوم الشعر عند السجلماسي. r ـ قضية اللفظ والمعنى: تبدو مناقشة السجلماسي

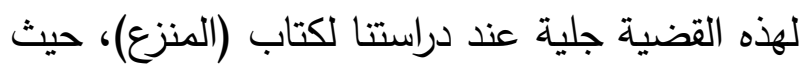
يؤكد أهمية مساوقة اللفظ والمعنى دون شذوذ أو لئه تنافر، وعدم تقوق اللفظ على المعنى بالحشو 
يتصدى السجلماسي لهذا الكلام ويوضحه معللا،إذ يقول: "لقد بلغ هذا الكلام معاوية فقال: شك أبو الأسود، فرد أبو الأسود على معاوية بآية قرآنية هي

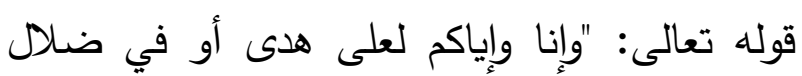

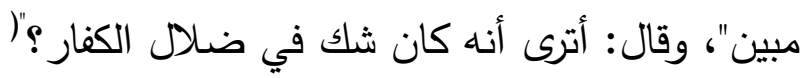

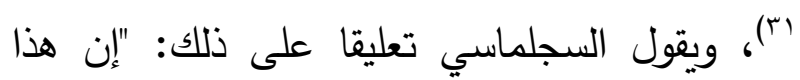

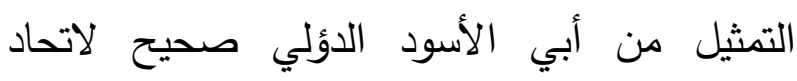
الصورتين، وارتقائهما معا إلى هذا النوع من إجراء

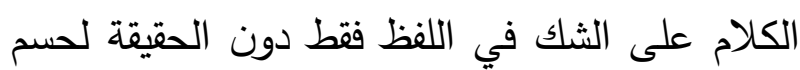
العناد، ويضيف السجلماسي لذلك: هذا النوع من علم البيان وأساليب البديع، هو من الكلام الرائق، والمبالغة الحسنة، ... فجمع السجلماسي هنا بين تحليل البيت الثعري وتحليل جدال أبي الأسود

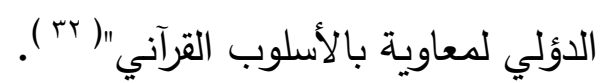
المبحث الثالث: جولة في عوالم المنزع: ربما آن لنا الآن أن نلج إلى عولى عالم المثلىع: عالمنا

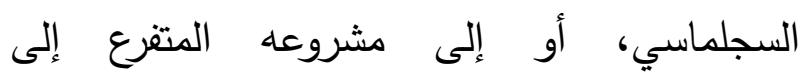
تخصصات كثيرة في النقد والبلاغة والأدب والفلسفة الكترعة إلى • والمنطق ا. ما الذي يريده السجلماسي ؟ عند الوقوف على مدخل (المنزع) نجده يقول: "قصدنا في هذا الكتاب إحصاء قوانين أساليب النظوم التي تثتمل عليها الصناعة الموضوعة لعلم البيان، وأساليب البديع، وتجنيسها في التصنيف وترتيب أجزاء الصناعة في التأليف على جهة الجنس
والتصور العقلي التنظيري من جهة أخرى هو الذي يعطي للفن صورته المطلوبة(^^). ه ـ السجماسي ناقدا ومحلا:

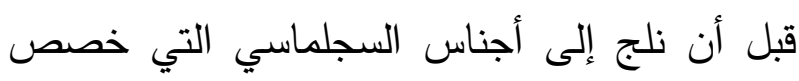

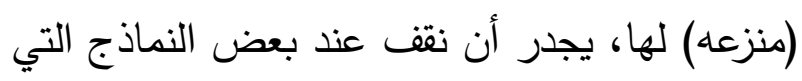

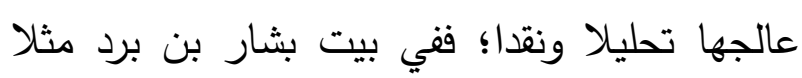

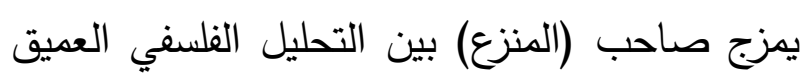

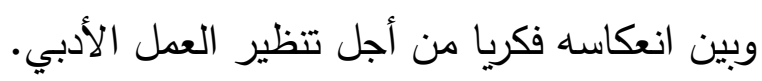

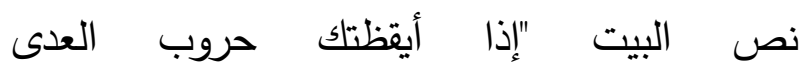
فنبه لها عمراً ثم نم"(ra ).

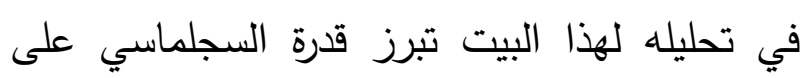
التحليق في الأجواء الفلسفية والمنطقية دون التخلي عن المنطلق البلاغي والنقدي؛ فقد طرح البيت في

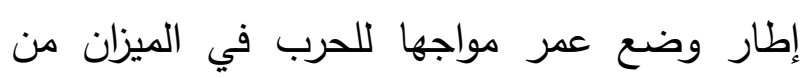
خلال التضاد بينهما في القوة والفعالية والتقابل، وانتهى إلى أن عمرا سيكون عاجزا لمواجهه الحرب

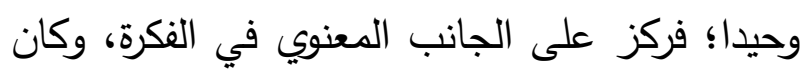
الحل برأيه أن نوقظ للحرب، ورأي عمر صائب،لأن الرأي والتخطيط هو الذي يجعل من عمر قوة قادرة على المواجهة. وفي تحليله لأبيات (أبي الأسود الألّي)، يسترسل

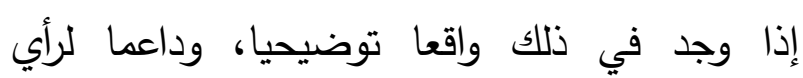
سيعطيه.

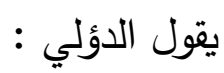
"أحب محمد حبا شديدا وعباسا وجعفر والوصيا"

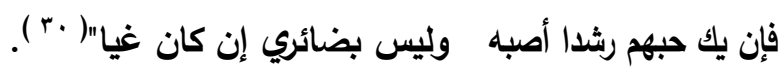


نبدأ بذلك الآن حرصا على لم شمل أفكارنا التي قد تتثتت إذا ما قمنا بعرض كل الأجناس المذكورة في منزع السجلماسي قبل جنس التخييل، بسبب تشعباتها وتغرعاتها الكثيرة، وسوف نتطرق لها بعد فراغنا من الموضوع الأهم لدراستتا هذه. r. التخييل موضوع الصناعة الشعرية: التخييل إذن هو مرادنا، وهو المنبع الأول الذي يروي الشعر بالحياة، ويغذيه، ويكفل له الارتقاء واستحقاق صفة الشعر الشعرية، هذا المنبع الأول الذي تتولد عنه روافده الأربعة، التي إن التقت جميعها كان الشعر شعرا وأدبا وفنا، وإن جف رافد منها، فقد الشعر والقول الشعري حجرا أساسيا من بنائه، ودعامة هامة من دعاماته، والروافد الأربعة هي:

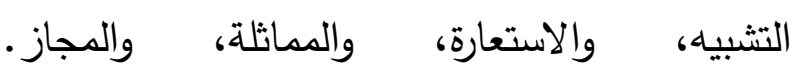
هكذا يراها السجلماسي؛ فهو يصنف التخييل جنسا ثانيا من ضمن عشرة أجناس تتضوي تحت راية علم البيان وصنعة البلاغة والبديع، والتخييل هو الموضوع الأساس الذي تتألف منه الصناعة الشعرية، وهذا التخييل والقول المخيل ينقسم إلى الأنواع الأربعة المذكورة سابقا. فكيف يرى السجلماسي ذلك ؟ ما هي الصناعة الشعرية؟ وما هي المحاكاة؟ ثم ما مفهوم صاحب المنزع للشعر والشعرية؟ وما رأيه بتلقي الشعر حين تقارنه بابن جيله العالم حازم القرطاجني الذي عاصره ؟ وهل تركزت الصناعة الشعرية بالتخييل وأنواعه، أو ببعض هذه الأنواع دون غيرها ؟ ثم ما با
والنوع، وتمهيد الأصل من ذلك للفرع، وتحرير تلك القوانين الكلية وتجريدها من المواد الجزئية"(rr" ). ومعنى ذلك أن السجماسي يريد أن يتتبع أسس الكتابة الفنية وأصولها وقواعدها، من خلال تقسيم كل قانون إلى (جنس عال) أو (قاعدة كلية راسخة) تبنى عليها فروع ذلك القانون وتتريعاته، ونلاحظ أن قوانين السجماسي هذه واقعة في علام البلاغة والبيان، وأنه يقنن أقسام صنعة البديع والبلاغة بعشرة أجناس بلاغية هي التي تقود الحالة الأدبية والإبداعية، وتزودها بالطاقة.

ويقصد السجلماسي بكمة (المنزع) : :"الهيئات الحاصلة عن كيفيات مآخذ الشعراء في أغراضهم، حتى يصل الكلام إلى صورة تقبلها النفس أو تمتتع من قبولها"( گr )،ي أنه يعني قوانين صياغة العملية الإبداعية الأدبية حتى تصل إلى حالة النضج والاكتمال.

أما الأجناس التي قسم السجلماسي كتابه إليها فهي حسب ترتيبه لها: " الإيجاز، التخييل، الإشارة، المبالغة، الرصف، المظاهرة، التوضيح، الاتساع، الانثناء ،والتكرير "(ro("). وحيث أن موضوع دراستنا الأساسي هنا، والمتعلق

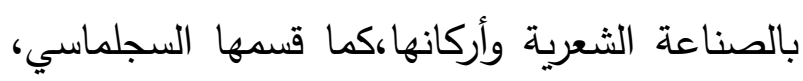
مفهوم الشعر والشعرية، التخييل والمحاكاة، وقد أدرجه السجماسي في إطار الجنس الثاني من الأجناس العشرة المذكورة وهو جنس"التخييل"، وحيث أن ذلك هو المحتوى الرئيس لهذه الدراسة، فسوف 
أرسطو، أو فيما عرفه الصصطلح من تطور على يد حازم القرطاجني في كتابه (منهاج البلغاء)"( (19).

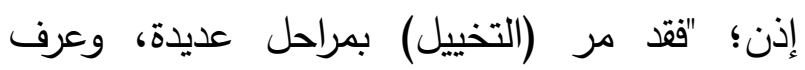

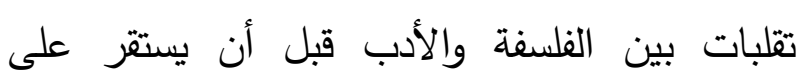
الصورة التي حملت دلالتها في الخطاب الثعري

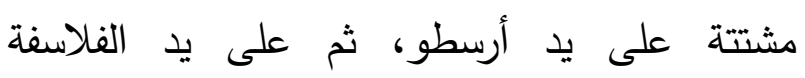

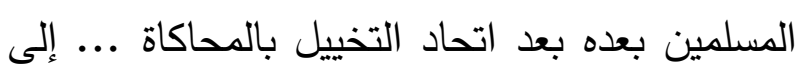

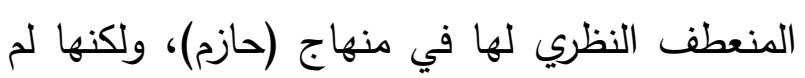

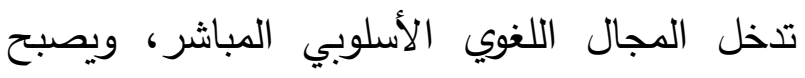
التخييل وما اشتق منه جزءا من النظرية البلاغية التية النقدية إلاعلى يد السجلماسي"(•؛ ). وعند دخولنا إلى (جنس التخييل) في كتاب الدنزع، نلاحظ أنه يقصد بالتخييل، الاستخدام المتميز للغة

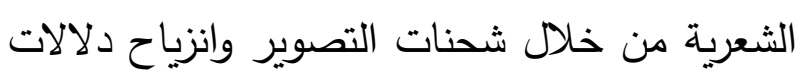
الكلام بعلاقات المقارنة أو النسبة أو الإبدال، بالإضافة إلى إثارة مصطلح التخييل إلى مكوناته من تشبيه واستعارة وتثثل ومجاز، وأنه مرادف للمحاكاة، والأهم من ذلك أنهاته الجوهر الأساس وناس

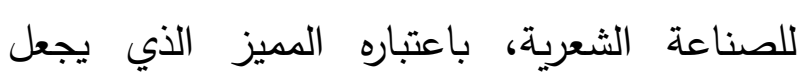
الشعر مختلفاً عن الاستخدامات الأخرى للغة لألغئ

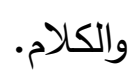

ثم يأتي السجلماسي إلى تعريف الشعر وتنسيره، لخلط العلماء بين الأقاويل الثعرية مع الخطبية تفسيرا مقنعا، ثم يأتي إلى معنى (القول المخيل) وتحليله وأنواعه التي هي نفسها مكونات (التخييل). r r ـ ماهية الثعر وحقيقته عند السجلماسي:
الذي يدعو السجلماسي لوضع تلك القواعد للعملية

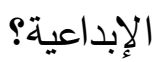

يقول السجلماسي في مطلع جنس التخييل: "هذا الجنس من علم البيان يشتمل على أربعة أنواع

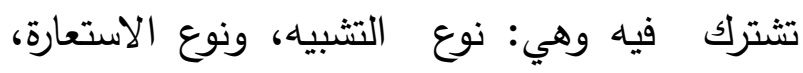

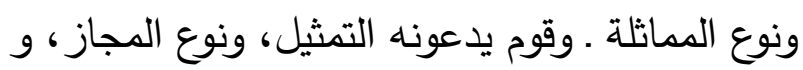
وهذا الجنس هو موضوع الصناعة الثعرية"( (ب) ). كما يجعل التخيل مرادفاً للدحاكاة والتشثيل، يقول:والتخييل هو المحاكاة والتمثيل، وهو عمود الشعر، إذ كان به جوهر القول الشعري وطبيعته ووجوده بالفعل (rv )، ويشاكل السجلماسي الفلاسفة المسلمين السابقين في أن التخييل هو الثريان الحي

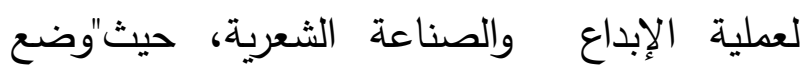
الفلاسفة المسلمون الأصول النظرية لموضوع

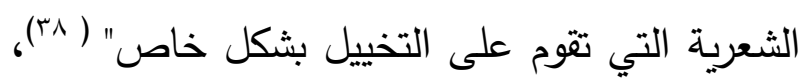
حيث كان ذلك واضحا في آراء الفارابي وابن سينا والجرجاني، وكذلك جازم القرطاجني المعاصر ل اللسجلماسي. كما أن التخييل كان قد نشأ قبل السجلماسي بزمن

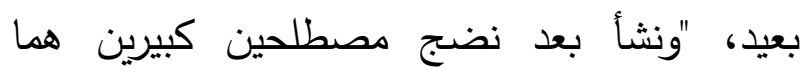
:التخيل والمحاكاة، حيث ولد التخييل وتطور في كياتي المباحث السيكولوجية الأرسطية، والتطورات التي عرفتها على يد الفلاسفة المسلمين من الكندي حتى ابن رشد، ونشأت المحاكاة وتطورت في المباحث النقدية والأدبية سواء في فن الشعر والخطابة عند 
الموضوعات خلال الصفحات القادمة، وكيف أضفى

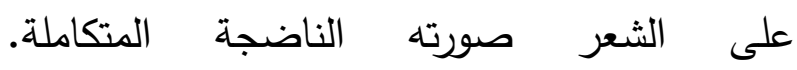
ثم يؤكد السجماسي على إشكالية الشعر بين مفهومه وعلاقته بالخطابة وسبب تلك الإشكالية، حيث يقول:"والسبب في ذكر أصحاب علم البيان ومتأدبي العرب هذا الجنس مختلطا، هو أنهم لم يكونوا تميزت لهم الأقاويل الشعرية من الأقاويل الخطبية، ولم يتبين لهم ما يخص صناعةً صناعة، بل كانت مختلطة عندهم، والسبب هو التباس كلياتها بموادها وعسر انتزاعها منها"(ع ؟). أي أن السجماسي يريد أن يحدد الشكل التام والناضج للشعر، رغم أن تعريفه له نجده عند ان سينا وحازم القرطاجني نقلا عن أرسطو، كما نجده عند العرب في عصور الأدب المختلفة، "واستخدامه لتعريف ابن سينا للشعر يخدم مدخله إلى تتاول الشعر بوصفة بنية لغوية متميزة تعتمد على التخييل، فضلا عن الوزن والقافية، وهي عناصر تتعلق بالشكل والصياغة على المستوى الصوتي (الوزن والقافية)، والمستوى المعنوي الدلالي (التخييل)، وهي عناصر أساسية في تمييز الشعر عما عداه من

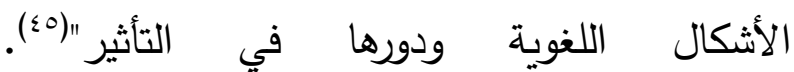
ثم يبين السجلماسي في جنس (التخييل) من كتابه (المنزع البديع) معنى القول المخيل، يقول:"إن القول المخيل هو القول المركب من نسبة أو ينسب الثيء إلى الشيء، تركيبا تذعن له النفس فتنبسط عن أمور وتنقبض عن أمور من غير روية وفكر "( ب؛)، بمعنى
يعرض السجماسي رؤيته للشعر في مستهل جنس التخييل إذ يقول:"الثعر هو الكلام المخيل المؤلف من أقوال موزونة متساويتة، وعند العرب مقفاه"(اء). ثم يبين دلالة تلك الأقوال الموزونة والمقفاه بقوله:"فمنى كونها موزونة؛ أن يكون لها عدد إيقاعي، ومعنى كونها متساوية؛ هو أن يكون كل قول منها مؤلفا من أقوال إيقاعية؛ فإن عدد زمانه مساو لعدد الآخر، ومعنى كونها مقفاه؛ هو أن تكون هون الحروف التي يختم بها كل قول منها واحدة"( rء). ثم يؤكد بعد ذلك أن "التخييل هو جوهريته والمشترك للجميع، وينبغي أن يكون موضوعها ومحل نظرها $(\leqslant r)$ ونحن نرى -تعليقا على تعريف السجلماسي ذلكأنه لم يأت بجديد في معنى الثعر وتعريفه لله، حيث أن تعريف الشعر عند العرب بجميع عصورهم حتى لتى منتصف القرن العشرين تقرببا، كان متقاطعاً مع تعريف السجماسي؛ فعبارة (الشعر هو الكلام الموزون المقفى، وله معنى)، عبارة لا يختلف عليها اثنان منذ العصر الأدبي في الجاهلية وحتى ما قبل عصر الحداثة الشعري، ولكن الذي يمكن أن يكون جديدا نوعا ما في الموضوع، ما يتعلق منه بالرؤينة العميقة للسجماسي في التخييل، واستشرافه للكثير من الآراء الشعرية التي ظهرت في العصر الحديث حول الخيال والصدق والكذب ووظيفة الثعر وتأثيره عند المتلقي، ومدرسة الفن للفن، والوظيفة الجمالية للشعر؛ حيث سنرى تقدم تفكير السجلماسي في هذه 
"قول جوهره هو القول المستفز للنفس، المتيقن كذبه، المركب من مقدمات مخترعة كاذبة تخيل أمورا وتحاكي أقوالا، ولما كانت المقدمة الشعرية إنما نأخذها من حث التخييل والاستفزاز، وكان القول المخترع المتيقن كذبه أعظم تخييلا وأكثر استفزازا وإلذاذا للنفس، وكلما كانت مقدمة الثعر أكذب..كان

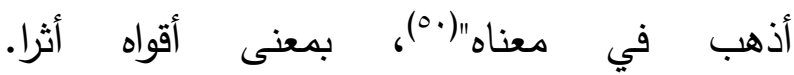
إذن، لنحاول أن نلملم مرة أخرى رؤية السجلماسي للشعر وما فيه من شعرية، وما يضمه من قضايا أخرى، وما نلمسه من تميز وإبداع، حيث يتبين لنا أن مفهوم الشعر عند السجلماسي قد "تجاوز ما جاء عند البلاغيين العرب القدماء من حيث ارتباط الشعر

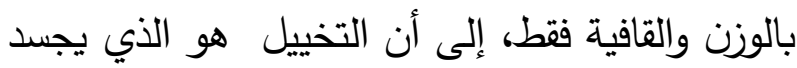
جوهر الشعر وعموده، كما أن مفهوم الشعر عنده قد إن الثرائ ارتبط بمفهوم الثعر عند الفلاسفة المسلمين الذين شرحوا كتاب فن الشعر لأرسطو، لكن السجلماسي قد

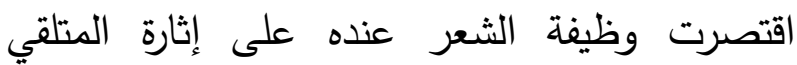
وإمتاعه واستفزازه، بينما ارتبط مفهوم الثعر عند الفلاسفة المسلمين على إحداثه اللذة، ومن ثم تحقيق توجيه معين لسلوك المتلقي نحو أهداف تربوية

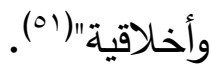

إذن ما يدل على رؤية السجلماسي الحداثوية للشعر رغم أنه عاش في القرن الثامن، هو تميزه في"تحديد ماهية الثعر حتى عن التيار النقدي الذي أفاد من لن لهن التراث الفلسفي، حيث ركز أصحاب هذا التيار في تعريفهم للشعر على أنه كلام منظوم بائن عن
أن "مفهوم الخيال عنده يتبين في التركيب المشتمل على شروط الارتباط والنسب والوصل بين الأشياء كضرورة حتمية لتمكين الأديب من صناعة يستطيع معها الانتقال من صورة إلى صورة ومن فكرة إلى فكرة في تسلسل وتلاحم ووحدة، كما يستطيع معها القارئ أن يتعاطف مع الأثر ويتتبع دلالاته الفنية

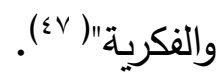

والسجلماسي في تقديمه لمعنى القول المخيل، يؤكد على"علاقة النفس بالحالة الفنية من حيث انسياقها

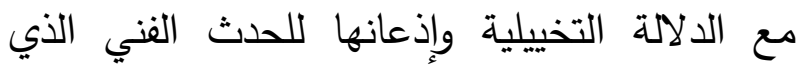
يحدثه فيها إحساسا واقتناعا بالنفس الناطقة، وقد

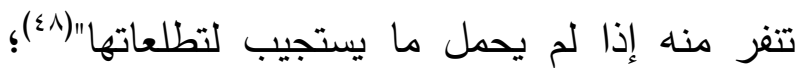
فهي إذن تتبط عن أمور وتتقبض عن أخرى تلقائيا من غير تقكير، كما يبين في عناصر القول المخيل سر الجاذبية الكامنة فيه، وإذعان النفس له، وسبب ذلك هو الالتذاذ الكائن للنفس الناطقة من إدراك النسب والاشتراكات والوصل بين الأثشياء؛ ويقصد السجلماسي بهذا أن من طبيعة النفس في رد فعلها حين تدرك بشيء أو بإثارة أدبية شيئا آخر ، أن لن

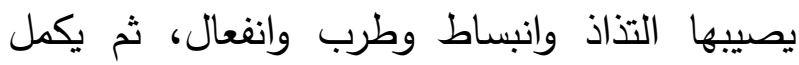
السجلماسي رؤيته للقول المخيل قائلا: "إذ كانت القضية الشعرية إنما تؤخذ من حيث هي مخيلة فقط

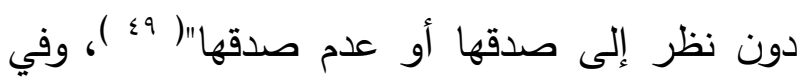
ذلك تجاوز لقضية الصدق والكذب في الشعر إلى الإيمان بالتخييل كمصدر لكل وحي وإلهام، وذلك يؤكده السجلماسي حين يقول عند حديثه عن المجاز 
تعريف الشعر، حيث لا يختلف تعريفه له عن تعريف ابن سينا وغيره من العلماء والفلاسفة، لكنه أعاد هذا التعريف وصاغه حتى أوصله إلى حالة

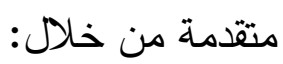
أ- التخييل والقول المخيل: والتخييل هو نفسه القول المخيل عند السجلماسي، ومعناه"|القول المركب من ون نسبة الثيء إلى الثيء تركيباً تذعن له النفس اله اله فتتبسط عن أمور وتتقبض عن أمور من غير روية وفكر"( (00)، وهذا التخييل هو ونيض أساس الثعر عند عنده، والمكون الرئيسي للشعرية في القول، والفنية في الشعر، أكثر من أي شيء آخر ذكره العرب السابقون، وقد بينا ذلك في تعريف السجلماسي للقول

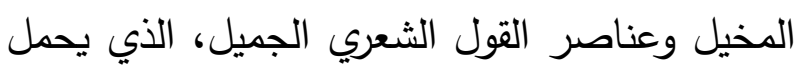

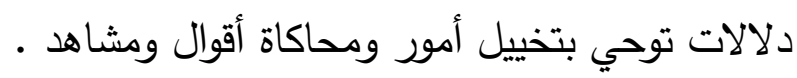
ب- موضوع والقافية والوزن: نعلم أن النقاد العرب التوات ومات

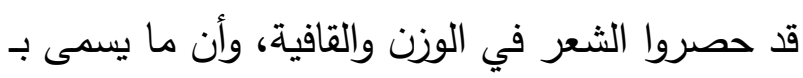

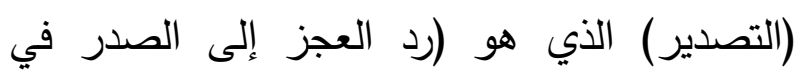
الكلام)، وما يسمى بالقافية خصوصا، هو عند

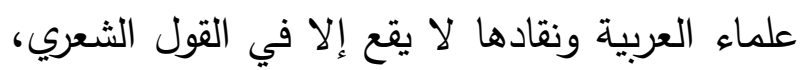
وبالتالي جعلوا ذلك ما يميز الثعر عن النثر أو غيره

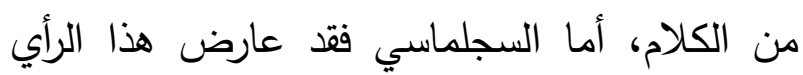
وقال:"التصدير هو رد أعجاز الكلام على صدوره،

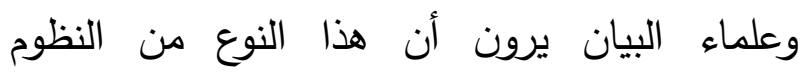
والتراكيب هو مخصوص بالقول الشعري وفي القوافي خاصة، ولذلك يبعدونه من القرآن الكريم ومن القول غير الشعري، ويرون أنه يوجد في الثعر فقط، فهل
المنثور الذي يستعمله الناس في مخاطباتهم بما

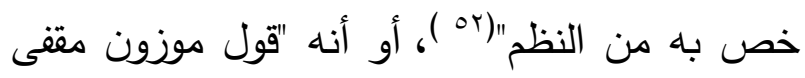

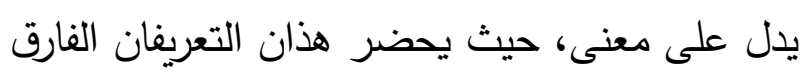
بين الثعر والنثر في الجانب الموسيقى المتحقق في

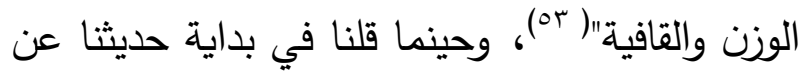
جنس التخييل في هذه الدراسة وتعريف السجلماسي للشعر ، إنه لم يأت بجديد في معنى الثعر أو تعريفه

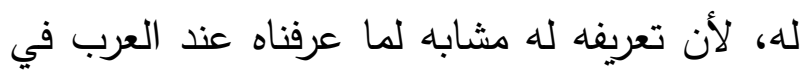

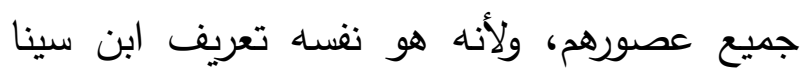

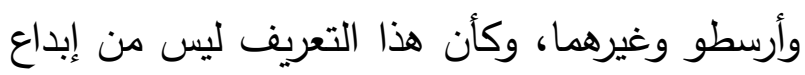

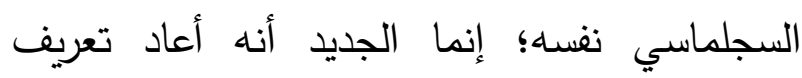
الثعر الذي ذكرناه سابقا في حديثه ببداية جنس التخييل، وأكد في مكان آخر من كتابه فهمه للشعر

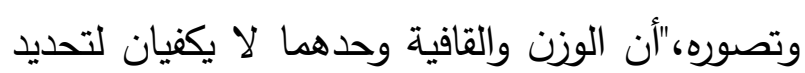
ماهية الشعر وجوهره، فالشعر يقوم على التخييل

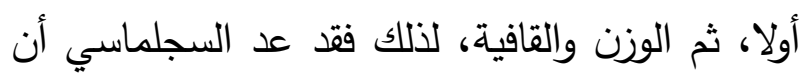
الفارق الأساسي بين الشعر والنثر هو التخييل، وأن

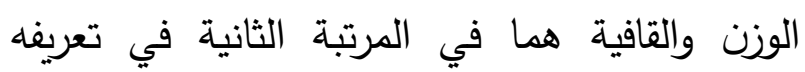
للشعر، بينما ركز العلماء السابقون على الوزن

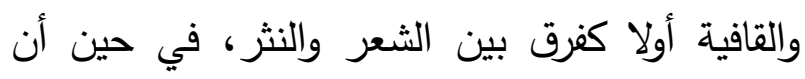
الوزن قد يكون في النثر العادي وكذلك القوافي المسماة بالفواصل في القرآن الكريم؛ فالقضية الرئيسة التي يثيرها السجلماسي هي أن الوزن والقافية ليسا الفارق الوحيد بين الشعر والنثر"( \&ه ).

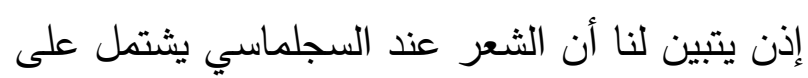
العديد من المعطيات والقضايا الإشكالية، وهي: 
كاذبة"(ه)؛ فالكذب إذن مرادف للتخيل الذي هو أهم مميز من مميزات الثعر والثعرية. د. ـ المتلقي وغرض الثعر : وما دام الكذب المثير

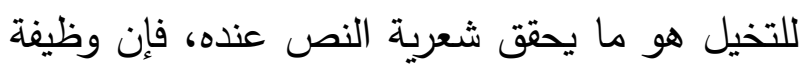
الثعر برأيه، تتحصر في إثارة انبساط المتلقي

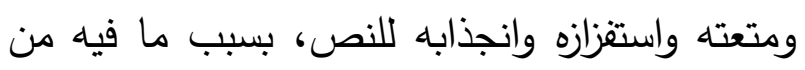

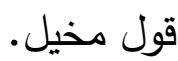
هـ ـ النفس والحالة الفنية: حيث أن النفس هي مصدر الوحدة الفنية، وإليها تعود، لاستيعابها وتذوقها، وتنبسط من أمور أو تتفر من أمور لأنها

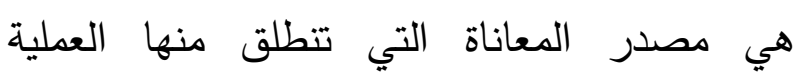

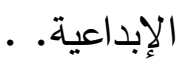

وبهذا نرى أن فهم السجلماسي للشعر، كان أشمل

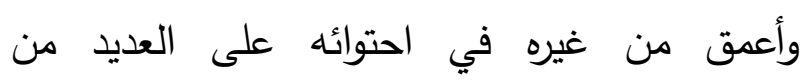
الإثكاليات والقضايا، ويذكرنا بحديثه عن التخييل بالحداثة الشعرية التي تطورت في القرن العشرين، وبعض ما في النصوص الأدبية الحديثة من تخييل وإثارة، وجعل المتلقي يشعر بالدهشة والحيرة والتحليق في عالم الخيال واللامرئي. ع. أركان التخييل وروافده الأساسية:

ربما يجدر بنا الآن أن ننتقل إلى الأنواع التي يرى التيلئ

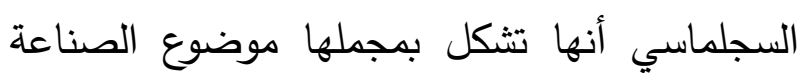
الثعرية المتمثل بالتخييل، هذه الأنواع هي الروافد

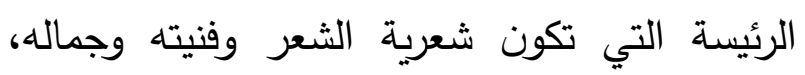
وبدونها لا تتشكل الحالة الإبداعية، أما هذه الأنواع

$$
\text { فهي أربعة وهي: }
$$

رأيهم هذا صدق؟.. وهم يعنون بالقول الشعري القول

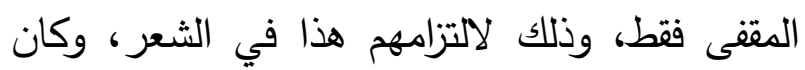
الوزن هو الفصل عندهم للشعر، لأنهم لم يشعروا

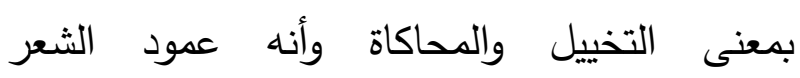
وجوهره" (107).

ثم يثبت خطأ رأيهم ذلك، قائلا:"إن ذلك غير مقصور على القول الشعري ولا مخصوص بالقوافي؛ فلو فحص قول غير شعري مردود العجز على الصدر دون وزن وقافية، لم يكن ممتنعا، وذلك كأن نقول: فلان سريع إلى الثر وليس إلى الخير بسريع، وفلان

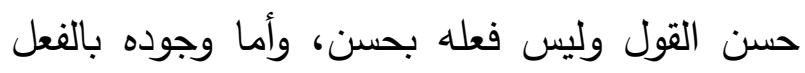

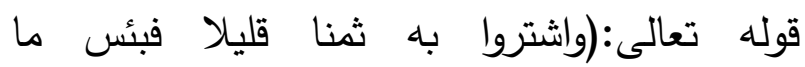

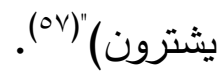
وهو يثبت بهذا أن (التصدير) بمعنى رد عجز الكلام

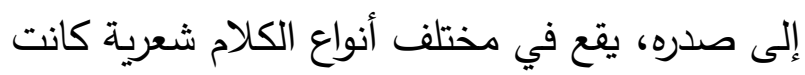
أو غير شعرية، وأن سبب غلط النقاد وغيرهم من فن فئن العلماء السابقين، هو اعتيادهم على القوافي والاعتياد للأقاويل الثعرية التي ترد فيها أعجاز الكلام إلى لى لـئي صدروها بسبب ورود العجز في القافية، ويثبت وجود

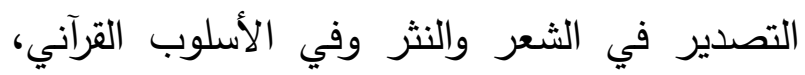

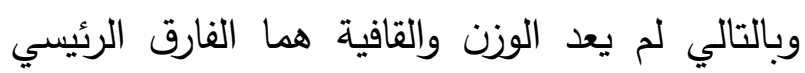
لتميز الشعر عن غيره، وإنما بالتخييل كما ذكرنا.

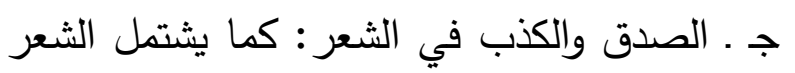
عند السجلماسي على موضوع الصدق والكذب، فهو عنده"القول المستقز المركب من مقدمات مخترعة 
يتبع بما يراد تخييله فيه وتشبيهه به، إما بالأداة وإما

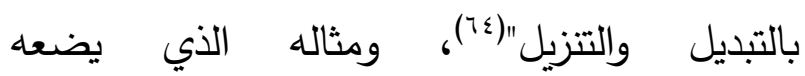
السجلماسي الآية "وله الجوار المنشآت في البحر كالأعلام"(70)، حيث ذكر المشبه أولا، ثم ذكر المشبه باه بعد ذلك، وأداة التشبيه حرف الكاف. وقوله:"فإذا انشقت السماء فكانت وردة كالدهان"(ד"7)، حيث ذكر المشبه أولا وهو السماء عند انشقاقها، ثم ذكر ما خيلها به وهو الدهان، باستخدام أداة التشبيه الكاف. ومثاله قول الشاعر أبي القاسم الزاهي: "أرى الليل يمضي والنجوم كأنها عيون الندامى حين مالت إلى الغمض"(TV). حيث نلحظ في هذا البيت أنه قد ذكر المشبه به أولا وهو (النجوم)، ثم ذكر ما شبهها به وهو (عيون الندامى)، وذلك باستخدامه لأداة التشبيه (كأن)، ولا يخفى للسامع حين يسمع هذا البيت ما فيه من شعرية، تتمثل بتخيله لصورة النجوم في آخر الليل ومقارنتها السريعة بعيون الندامى المثقلة بتأثير الشراب وتغيرها وتبدل حالها، فهذا الاستخدام للغة يثير متعة المتلقي وانبساطه الناتج عن حدوث التخييل. ب ـ أما النوع الثاني من التشبيه البسيط، فهو الجري على غير المجرى الطبيعي ويقصد السجلماسي به: "عكس التشبيه"(^^)، بمعنى" أن يكون الجزء الأخير من القول التشبيهي هو المشبه والموصوف، والجزء

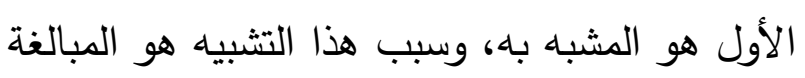

ا ـ التشبيه ب ـ الاستعارة ب ـ المماثلة (التمثيل)

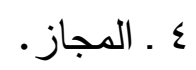
ا . ولنبدأ بالنوع الأول من أنواع التخييل وهو (التشبيه): يعرفه السجلماسي بأنه "هو القول المخيل وجود شيء في شيء، إما بأحد أدوات التشبيه الموضوعة لله كالكاف وحرف (كأن) أو (مثل)، وإما على جهة التبديل والتنزيل"(09). ومثاله قول امرئ القيس: "وليل كموج البحر أرخى سدوله علي بأنواع الهموم ليبتلي" (7). ويقول بتعريف آخر: وقال قوم:"التشبيه هو صفة الشيء بما قاربه وشاكله من جهة واحدة، أو من

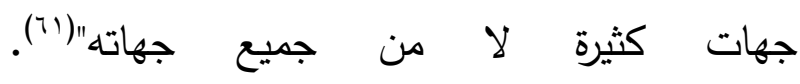
ومثال آخر، قول أبي تمام :

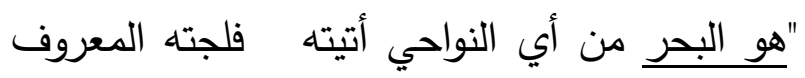
والبحر ساحله"(r"). ودلالة التشبيه اضثثالين. ثم يقسم السجلماسي التشبيه نوعين آخرين هما: I ـ البسيط ب ـ المركب. فالتثبيه البسيط هو نفسه التعريف السابق وهو"القول المخيل المشبه والممثل فيه شيء بشيء، ويعني ذاتا مفردة بذات مفردة من جهة واحدة أو أكثر "(r) (r) وهذا التثبيه البسيط نوعان أيضا وهما: أ ـ الجري على المجرى الطبيعي: ويقصد به في التخييل والتمثيل"أن يبدأ بما يراد تخييله وتشبيهه، ثم 
حالة من الشعور بالمتعة والانفعال، من خلال العلاقة الوثيقة بين التشبيه والصورة الثعرية، فيتحقق بنق بذلك الهدف من القول بتفاعله مع جميع كلمات البيت أو مكونات القول الشعري، لخلق الإشارات

التي تصنع التخييل والاستفزاز • التئ r ـ نأتي إلى النوع الثاني من أنواع التخييل حسب تقسيم السجلماسي، وهو المكون الثاني للشعرية، وهذا النوع هو (الاستعارة)، والاستعارة "ليست تغيرا في المعنى، بل في طبيعة المعنى ونمطه، وهي انتقال من المعنى المفهومي إلى المعنى الانفعالي، بمعنى

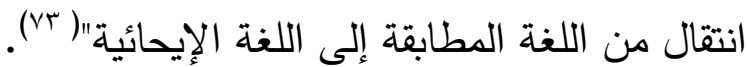

يقول السجماسي:"الاستعارة هي أن يكون اسم ما دالا على ذات معنى معروف به دائما من أول ما ليا وضع، ثم يلقب بهذا المعنى والاسم شيء آخر

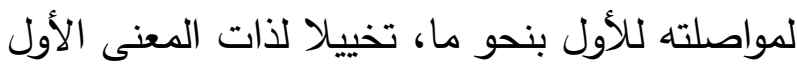

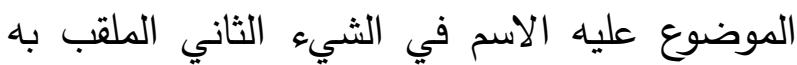
حين اللقب، من غير أن يجعل مثبتا للثاني دالا على

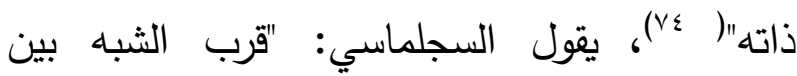
المستعار منه والمستعار لله، وتحقق النسبة، وامتزاج اللفظ بالمعنى دون منافرة"(vo (vo). ويقصد السجلماسي بهذا التعريف المعنى المعروف لهفي للاستعارة، وهي: استعمال اللفظ في غير ما وضع له أصلا لعلاقة المشابهة، مع قرينة تمنع من إرادة المعنى الأصلي، وهي إعارة اسم المشبه به للمشبه
في التخييل والوصف" ( 79)، ويمثل السجلماسي لهذ النوع من التشبيه بقول الثاعر البحتري:

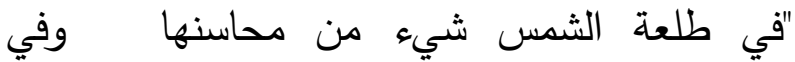

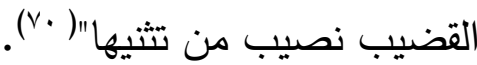
إن المشبه به هنا هو (المحاسن) وقد جاءت في أخر الشطر، والمشبه به هو (طلعه الثمس) وقد جاء في الجزء الأول من القول لغرض الغلو والمبالغة؛ حيث عكس التشبيه هنا بذكر المشبه به قبل فيل المشبه، مما يثير المتلقي ويترك عنده أحسن الوقع لهن لهن الناتج عند مفاجئته بـ(طلعة الثمس)، قبل أن يعرف

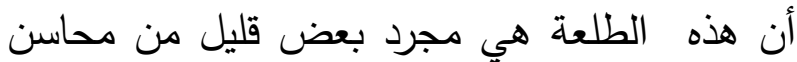

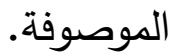
والنوع الثاني من التشبيه بصفته ركنا من أركان التخييل هو (التشبيه المركب)، ويقصد به بله السجلماسي:"أن يقع التخييل في القول لشيئين بشيئين، والمشبه والمشبه به ذوات كثيرة، وينتظ

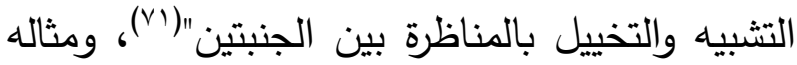
التوضيحي قول بشار بن برد:

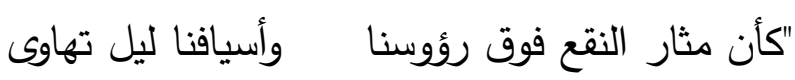

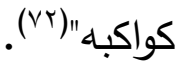
فالمشبه هو النقع والأسياف ووقعها، والمشبه به هو الليل وكواكبه التي تهوي، وانتظم التشبيه بمناظرة

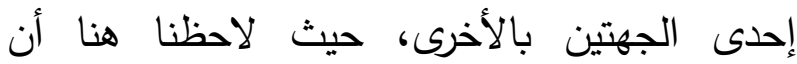
المشبه أكثر من شيء واحد، والمشبه به عدة أشياء أيضا، وهذا مما يجعل المتلقي محتارا ومندهشا بها بببب التخييل الذي وقع في القول؛ فتحدث عنده 
اللغة بدور محدد: هو التوصيل فحسب، فتستخدم وإجراؤه عليه. الألفاظ بدلالتها المباشرة المحددة، وتصبح الألفاظ عندئذ إشارات إلى دلالات ومعان ثابتة، أما المستوى

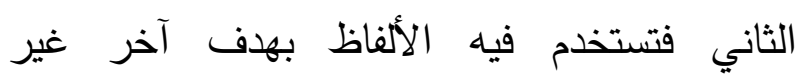
التوصيل، هو التخييل أو التأثير، ومن هنا تستخدم الألفاظ استخداما تتحرف فيه عن الاستعمال الحرفي المباشر ، فتصبح مشحونة بدلالات متتوعة متعددة، من خلال إقامة علاقات جديدة بينها، تعتمد على

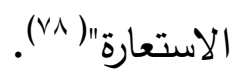

وهذا يعني أن المتعة والشعرية في النص لا تتحقق إلا باستخدام الألفاظ الموحية، التي تطلق العنان للمتلقي كي يحلق فيما يسمع، تحليقا يجعله منطلقا في ما أوحت به اللفظة، لا بما يعرف عنها من معنى لغوي تقليدي. r ـ أما (المماثلة) أو (التمثيل)؛ فهي المكون الثالث

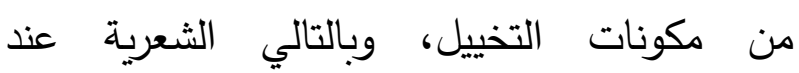
السجلماسي، يقول السجلماسي في مستهل تعريفه لها:"وحقيقتها التخييل والتمثيل للثيء بشيء لله إليه نسبه، وفيه منه إشارة وشبها....وذلك أن يقصد الدلالة على معنى، فيضع ألفاظا تدل على معنى آخر، ذلك المعنى بألفاظه مثال للمعنى الذي قصد الدلالة عليه"(V9). وقد عد المماثلة نوعا من الإشارة أو الكتابة، "وهو خروج باللغة من دلالتها الصريحة إلى معناها الانفعالي والفني"(•^)، كما "ربط السجلماسي المماثلة بالمتلقي من حيث إحداث اللذة والمتعة الفنية"( (^)،

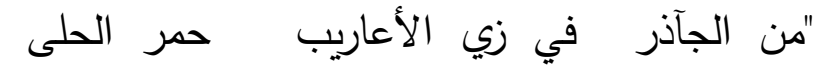

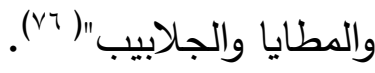
حيث استعار الثاعر لفظة (جآذر) وهي جمع

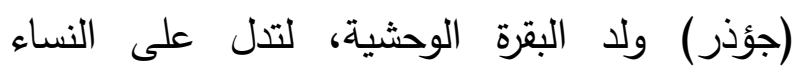

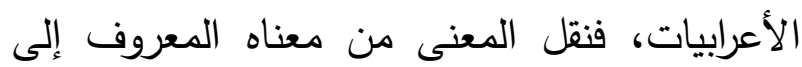
معنى آخر جديد، وهناك علاقة مشابهة بين (جآذر)

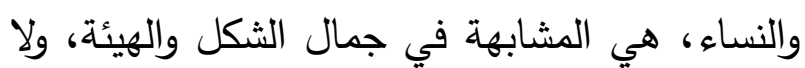
شك أن هذا الأسلوب من القول هو في غاية الحسن هن والجمال، الناتج عن إخفاء المشبه وإظهار المشبه

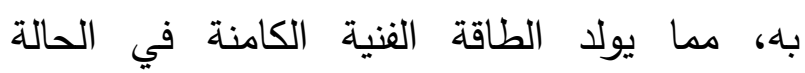
الإبداعية، وبالتالي تترك مفعولها واقعا على المتلقي.

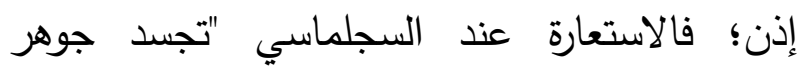
العملية الثعرية وطاقتها الفنية، وقد حدد السجلماسي مجال الاستعارة الذي يختلف عن مجال اللغة

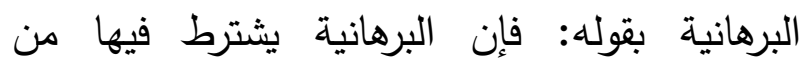
استعمال الألفاظ الأصلية والنظوم الأصلية غير فئن

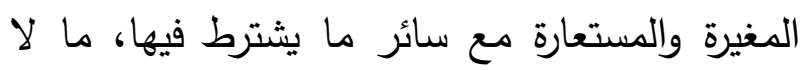

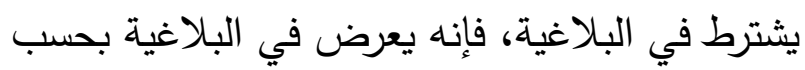

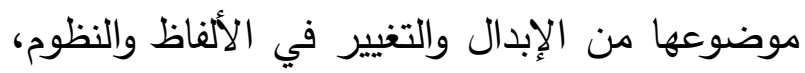
عوارض توجب استعمال النظوم غير الأصلية المغيرة"(VV) ( فالسجلماسي "يفرق هنا بين العبارة البلاغية،وهي

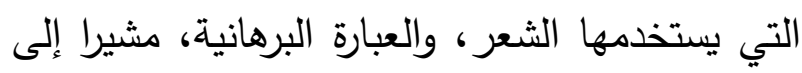
مستويين لغويين متمايزين، في المستوى الأول تقوم 
ويقول في ذلك:"... فمن قبل ذلك كان له في النفس تخييلا واستفزازا ل لمزيد الغرابة، ولولوع النفس

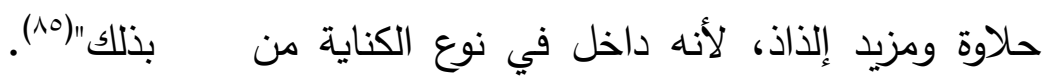

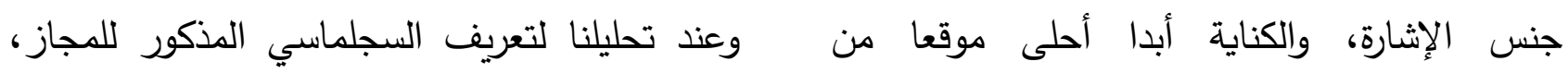
نتذكر رؤية السجلماسي للشعر، ونظرته للمتلقي،

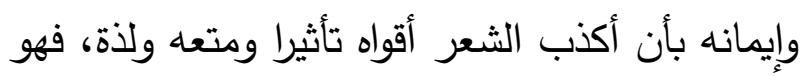
يقرن المجاز صراحة بالكذب بقوله (القول المستفز للنفس المتيقن كذبه، المركب من مقدمات مخترعة لئرة كاذبة...)، ويبين العلاقة القوية بين المجنية لمعاز والتخييل، بقوله (ولما كانت المقدمة الثعرية إنما نأخذها من حيث التخييل والاستفزاز فقط، وكان القول المخترع المتيقن كذبة أعظم تخييلا وأكثر استفزازا...)،كان -ويقصد المجاز - أذهب في معناه وأقعد أنواع الجنس بفعل التخييل، "وبهذا يصبح المجاز عند السجلماسي أشد أنواع جنس التخييل خصوصية بالتخييل، وأعظم أنواع التخييل استغزازا

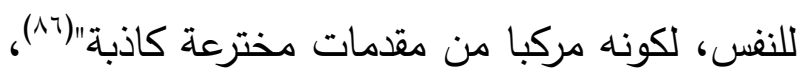
ولهذا "فالأنواع الثلاثة الأولى للتخييل، وهي التشبيه والاستعارة والمماثلة (التمثيل)، هي أقل درجة في

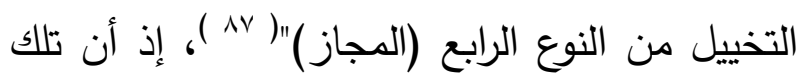

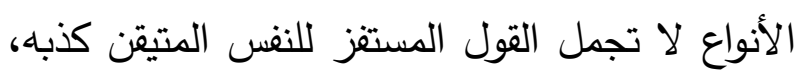
ولا تتركب من مقدمات مخترعة كاذبة. ويقودنا هذا إلى القول بأن الصناعة الشعرية عند السجلماسي قد تركزت بجميع أنواع جنس التخييل،

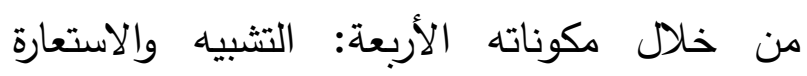
والمماثلة والمجاز، غير أن المجاز هو أكثر هذه

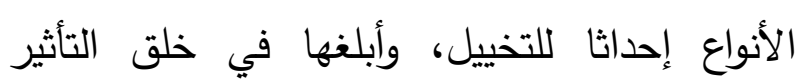

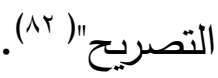

ومن الأمثلة التي يسوقها السجلماسي على المماثلة قوله تعالى : "وثيابك فطهر"(^r)، وهو يقصد (نفسك)، ولا يخفى أن استخدامه لكلمة الثياب يعد مماثلة، لقصده تطهير النفس لا مجرد تتظيف ثياب. وقول امرئ القيس:"وما ذرفت عيناك إلا لتقدحي بسهميك في أعشار قلب مقتل فتمثل عينيها بسهي الميسر، وهما: المعلى وله سبعة أنصباء، والرقيب وله ثلاثة أنصباء، فصار

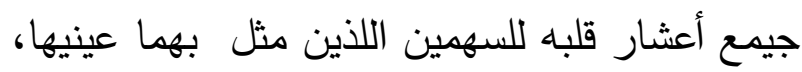
ومثل قلبه بأعشار الجزور ، فتمت له المماثلة"(ع^).

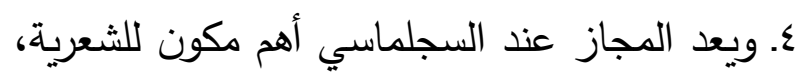

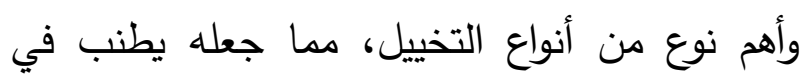

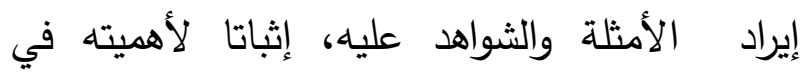
تحقيق التخييل وتكوين شعرية النص الشعري.

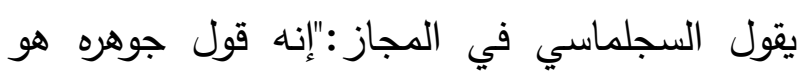

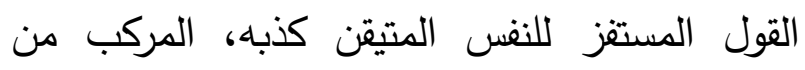
مقدمات مخترعة كاذبة تخيل أمورا وتحاكي أقوالا،

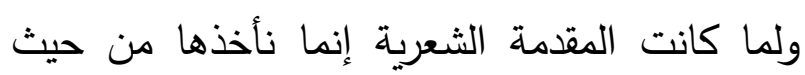
التخييل والاستفزاز فقط، وكان القول المخترع المتيقين كذبه أعظم تخييلا وأكثر استفزاز ، وكلما كانت مقدمة القول الشعري أكذب، كانت أعظم 
البديع، أو بعض الأنواع المتفرعة عن تلك الأجناس، ومنها:(الاكتفاء)، الذي جعله السجلماسي نوعا من النواع الني أنواع الإيجاز ، حيث بين السجلماسي العلاقة الوثيقة

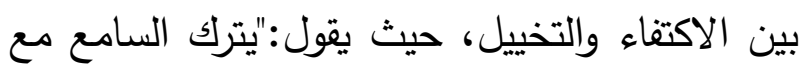

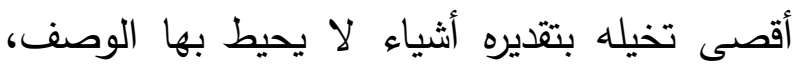

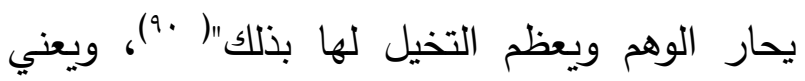
بذلك قوة التأثير التي تفاجئ المتلقي حي يحلق

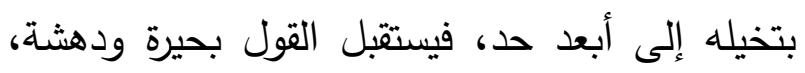
والاكتفاء هو :"قول مركب من جزئين فيه مرتبطين،

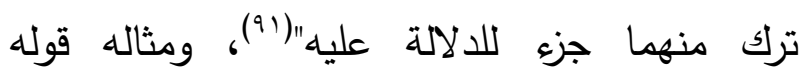

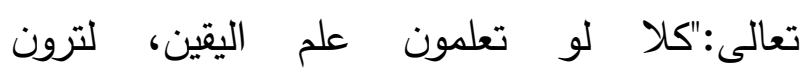

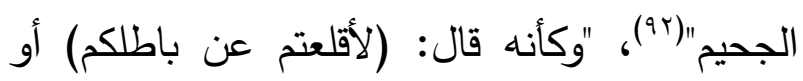
(لتحققتم مصداق ما تحذرون منه)، فالجواب إذن باطن محذوف لقصد المبالغة، ليترك السامع مع تخيله

لكإحاطة بالثيء "(9r).

كما يعد نوع (الاقتضاب) -وهو أحد أنواع جنس بلأس الإشارة- مكونا رئيسا للشعرية، وتابعا للتخييل

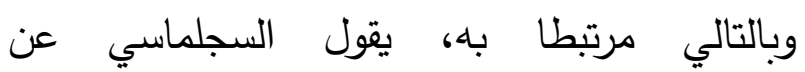
الاقتضاب:"هو اقتضاب الدلالة، وذلك أن يقصد الدلالة على ذات معنى فيترقى عن التعبير المعتاد،

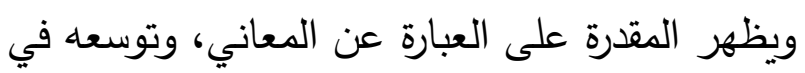
نطاق الكلام، فيقتضب في الدلالة عليه"(§a).

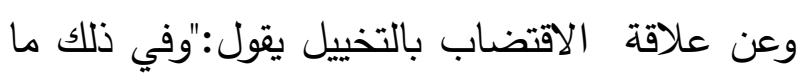

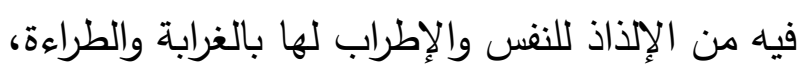

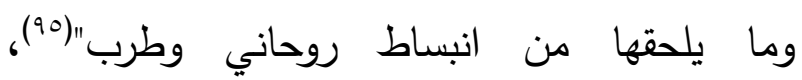

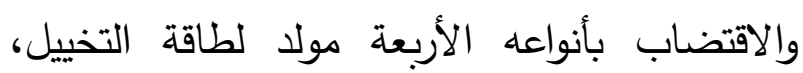

والانفعال، وبالتالي تكوين ما يسمى بالشعرية للنص

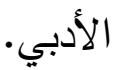
هذا وقد أورد السجلماسي شواهد كثيرة على المجاز ومنها قول أبي العلاء المعري: فما صدقت ولا " تخيلت الصباح معين ماء

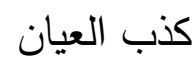
فكان الفجر تشربه المطايا وتملأ منه أسقية

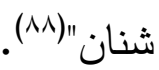

وبهذا فإن المجاز يعد من "أهم وسائل خلق الصورة

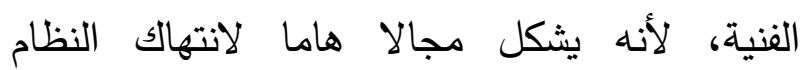
اللغوي، والخروج على مألوفة والتوسع فيه، ولذا فقد

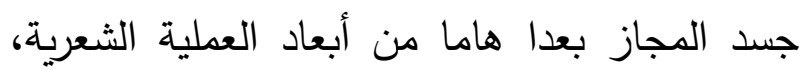

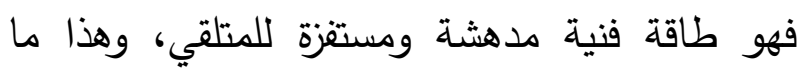
يحدث اللذة والمتعة لديه من خلال الطاقة الفنية

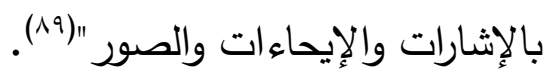
0. مخيلات أخرى (مصادر مكونات للشعرية):

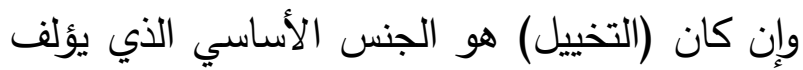

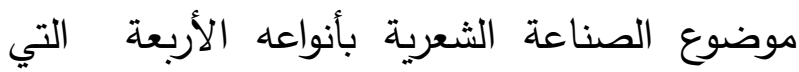
عرفناها، فلا يعني ذلك توقف المكونات الشعرية عند ذلك الجنس فقط؛ فما دام علم البيان والبديع والعبارة البلاغية هو الذي يزود الثعر بطاقته الفنية

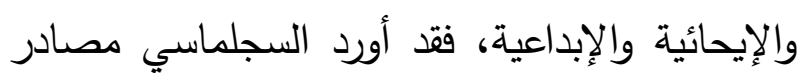

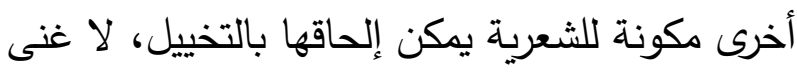
للشعر عنها ليكون فنا وإبداعا راقيا، ومحدثا للانفعال ومزلزلا لما هو خامد وجامد، ومن تلك المكونات أجناس عديدة تطرق لها السجلماسي في منزعه 
ينجذب للعمل الشعري من خلال ما يحدثه من لذة وإطراب للنفس" ( + (1). كما يعد نوع (الغلو) مكونا من مكونات الشعرية والتخيل، يقول السجلماسي: "وهو يرادف الإفراط، ويقصد الإفراط في الإخبار عن الشيء، ومجاوزة الحقيقة للخيال المحض والكذب المخترع"( \&.')، والغلو نوع من أنواع جنس المبالغة، حيث نلاحظ مدى ما يقوله السجلماسي عنه، وما قاله عن الشعر وتميزه بالتخييل، مما يدل على صلة الغلو بالتخييل وما يتركه من أثر في نفس المتلقي. ومثاله قول الأعشى:

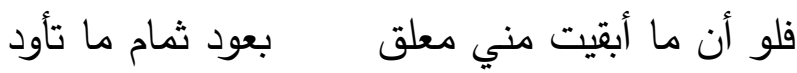
عودها والثمام نوع من النبات الضعيف، حيث نلاحظ الغلو والإفراط في وصف الأعشى لنفسه، مما يحدث لذة عند السامع وطربا ومتعة(100). ومن عناصر الشعرية أيضا نوع (المطابقة)، الذي وضعه السجلماسي ضمن جنس (المظاهرة)، حيث يقول: إن المطابقة هي "المخالفة والمنافرة"( 4.1) وهي "قول مركب من جزأين كل جزء هو عند الآخر

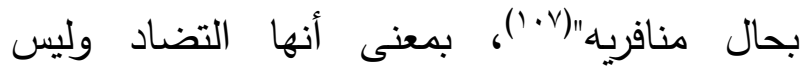
التجانس، والتضاد يجعل المتلقي متفاجئا لما هو غير متوقع في القول، مما يسهم في تكوين الخيال والإمتاع عنده، ومن أمثلة السجلماسي على المطابقة قول الرسول (ص): "فليأخذ العبد من نفسه لنفسه، ومن دنياه لآخرته، ومن الشبيبه قبل الهرم، والحياة
وأنواعه: التتبع والكناية والتعريض والتلويح، وكلها تعني"|قتضاب الدلالة على الشيء بلازم من لوازمه أو بماله إليه نسبه أو بنقيضها أو بنظيره"(97). ومثاله قول امرئ القيس: "ويضحي فتيت المسك فوق فراشها نؤم الضحى لم تنتطق عن تفضل فهنا أراد أن يصفها بالترف والنعيم والغنى؛ فجاء بما هو تابع لذلك بلازم من لوازمه، وهذا يسمى اقتضاب تتبيع"(وه)، وقوله في مثال آخر الآية "وقالوا لجلودهم"(19)، يعني (فروجهم) وهذا اقتضاب كناية، وعبر عن المعنى بما له إليه نسبة(99)، والآية "إنك لأنت الحليم الرشيد"(·')؛ ففي هذه الآية اقتضاب في الدلالة على معنى الفظاظة والضلال عند المشركين، وعبر عنه بنقيضه وهو (الحلم والرشاد)، وهذا اقتضاب تعريض (1 (1). وعن الاقتضاب أيضا قول النابغة الذبياني:

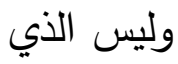
تطاول حتى قلت ليس بمنقض يرعى النجوم بآيب الثاعر يقصد هنا الصبح، وقد جعله الثاعر محل الراعي الذي يخرج وقت الغداة بماشيته، وفي هذا البيت اقتضاب تلويح، بمعنى اقتضاب الدلالة على المعنى الغداة أو الثيء بنظيره وإقامته مقامه(r+(). إذن نلاحظ أن أنواع الاقتضاب التابع لجنس الإشارة "تعبر عن المستوى اللغوي الأول الصريح، والمستوى الثاني وهو المستوى الفني والانفعالي، الذي به يتم خلق علاقة قوية بين العملية الشعرية والمتلقي، الذي 
وقال آخرون في تأويل القول نفسه: هو أمر عظيم،

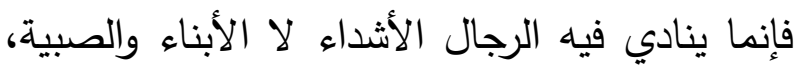

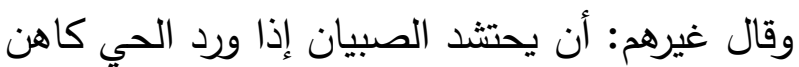

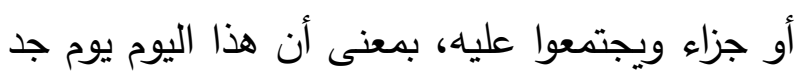
وتجرد، وليس يوم أنس ولهو، وفي تفسير رابع لقول:

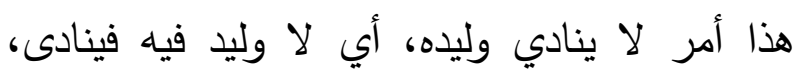

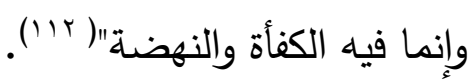
نلاحظ كثرة التأويلات واتساعها لتفسير قول واحد، وكيف ولدت محاولات التفسير خيال المفسر أو انفعاله، وذلك ركن هام من أركان الصناعة الشعرية، حيث التأويل متوقف على المتلقي، وهذا ما يجعله منجذبا للقول ومنفعلا معه شعرا أو نثرا. وتتزايد المكونات الأخرى للشعرية كلما قلبنا منزع السجلماسي، وهي مكونات لم يدرجها في جنس التخييل، لكنها عوامل مؤكدة في تكوين التخيل، وتصوير الغائب، وشعرية النص وفنيته. ومن تلك المكونات نوع (الالتفات)، الذي رتبه وتئه السجلماسي ضمن جنس (الانثناء)، يقول: "هو خطاب التلون، وهو تردد المتكلم في الوجوه، وفائدة هذا الأسلوب من النظم والفن، استقرار السامع والأخذ بوجهه، وحمل النفس بتتويع الأسلوب، وطراءة النطاء

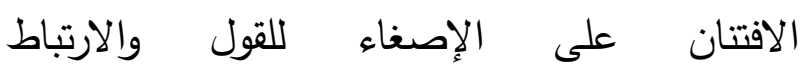

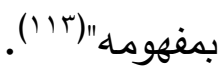

ونلحظ مدى ارتباط هذا القول بفكرة الانفعال والاندهاش والمتعة، وهي أبعاد تهم المتلقي كونها هي التي تجعله يقبل على القول وينجذب له أو ينفر
قبل الممات"(1+1)؛ فالمطابقة في قول الرسول -عليه الصلاة والسلام- هي بين (دنياه-آخرته) و(الثبيبهالهرم) و (الحياة-الممات)، ولو سمع المتلقي مثل هذه لهن المتضادات، لأدرك مدى تأثيرها في النفس، وإحداثها للخيال واستحضار ما هو غائب. وكذلك في الثعر ما تحدثه المتضادات من متعة وانفعال لاى المتلقي، ومن شعرية وجمال وفنية، ومثال القول الشعري، قول البحتري: يا أمة كان قبح الجور يسخطها حسن العدل يرضيها حيث تتضح المقابلة بين الأضداد (كان ـ أصبح) و ولوضين

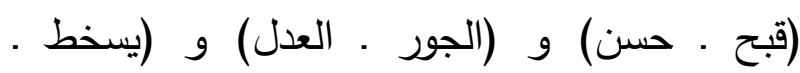

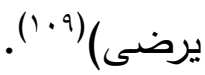
كما أن (الاتساع) -وهو الجنس الثامن في ترتيب السجلماسي لأجناسه العشرة- يعد مكونا هاما للعملية الشعرية والتخييل، وفي النثر كذلك؛ لأن السجلماسي لاجي ربط فهمه بتأويل المتلقي للقول الذي يسمعه، ولا

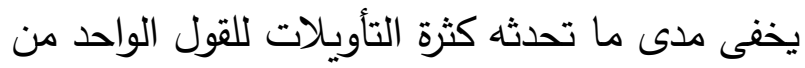
تخييل واستقزاز ومتعة، حتى لو خرج التأويل عن من لون القصد المراد من القول، يقول السجلماسي: "هو صلاحية اللفظ الواحد للاحتمالات المتعددة من غير لتول

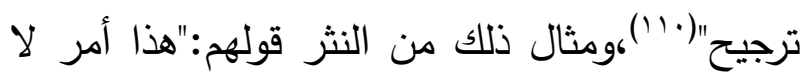
ينادي وليده"('")، فإن هذا القول واحد بلفظه، لكن تأويله قد اختلف عن من سمعه، فقال بعضهم في دلالته:"إن الإنسان يذهل عن ولده لثدة به، فيكون مثل الآية (يوم يفر المرو من أخيه، وأمه وأبيه)، لإنهان لهن 


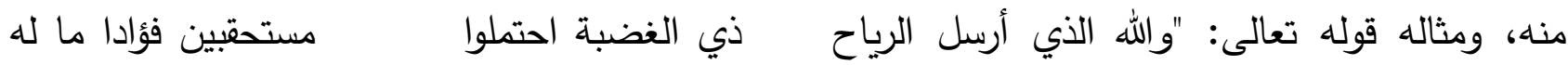

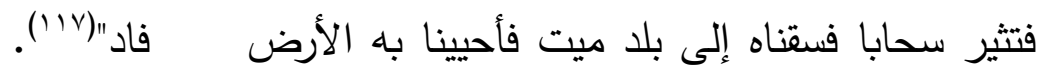
حيث يوضح السجماسي هنا "أثر الإيقاع الناتج عن الجناس على المتلقي من حيث اللذة والانفعال"(1')". ويقول السجماسي:"فؤاد من لفظ (ف عن دي د)، وفاد من

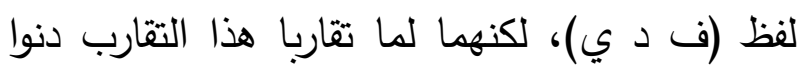
من التجنيس، والإخفاء بارتباط الانفعال هنا والارتياح

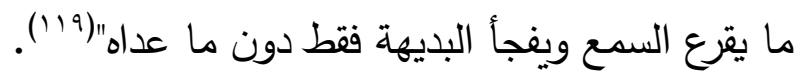

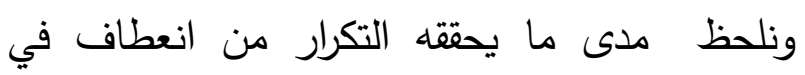
اللغة، وما يؤكده من شحنات مستفزة للسامع، ودلالة

فائضة بالقدرة على خلق الشعرية والحالة المؤثرة. ويتضح ذلك بشكل جلي في المثال الذي صنفه السجماسي تحت نوع (الاشتقاق التابع للتكربر)، وهو قول أبي نواس (rrir):

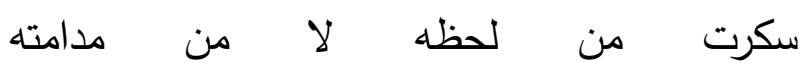
ومال بالنوم عن عيني تمايله

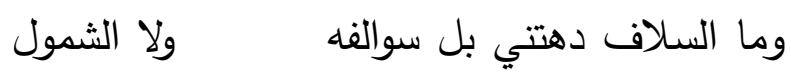
ازدهرني بل شمائله

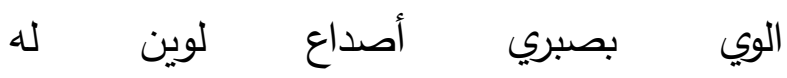
وغل صدري بما تحوي غلائله حيث نلمس في الأبيات المذكورة ما فيها من هزي هله للسامع وارتياح في نفسه، من خلال تكرير الألفاظ واشتقاقها (مال . تمايله)، (السلاف . سوالفه)، (الثمول .

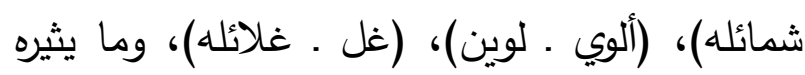
عند المتلقي من تخيل وتحليق.

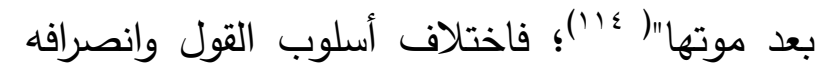
إلى أكثر من وجه هو الالتفات، ولو كان الأسلوب

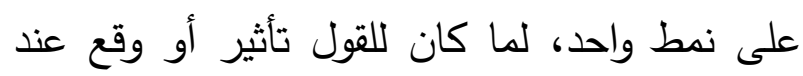
السامع، وفي الآية المذكورة التفات في القول، لأنه

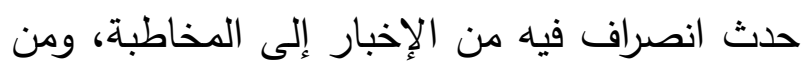
المخاطبة إلى الإخبار - المبن فالالتفات بهذا المعنى مصدر هام من مصادر الإنار

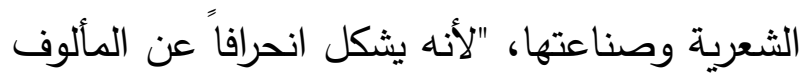
في اللغة، وهذه سمة الشعرية، التي هي خروج عن وناعن التهن المألوف إلى مجال جديد من التشكيل الفني"(10)" كما نكتشف وجود علاقة وثيقة بين جنس (التكرير)

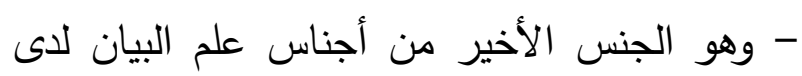
السجلماسي- وبين جنس التخييل، وبالتالي ما يعنيه

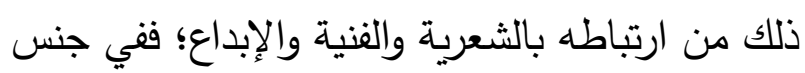
التكرير نجد نوعين مهمين تابعين له، يمكن أن يكونا عنصرين فاعلين لخلق الحالة الإبداعية وشعريتها، وهما (التصريف والاشتقاق). يعرف السجلماسي التصريف بقوله: "إعادة اللفظ الواحد بنوع المادة فقط في القولين بينائين مختلفي

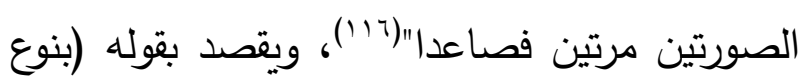

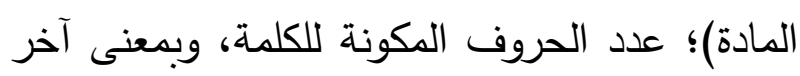
هو:لفظ يشتق من لفظ ويساويه بعدد حروفه وليس بينائه، دون الحاجة إلى أن يتفق اللفظان بأصلهما

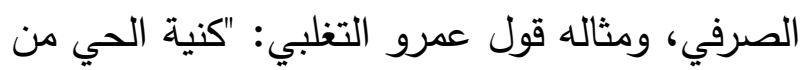


ويذكر أن العديد من أشكال التكرار تثكل -إضافة ومنه (تجنيس القلب)، كقول أبي إسحاق بن

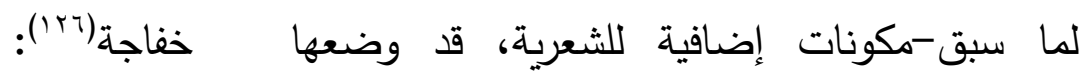
السجلماسي وحدد دلالتها بدقة بارعة، تشكل جميعها وسقى فأروى غلة من ناهل أورى بجانحتيه زند

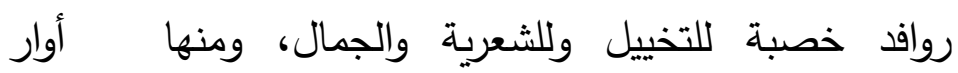
(التجنيس) بأقسامه المختلفة، وما يتفرع عنه من حيث نلاحظ تجنيس القلب في قوله: (أروى-أورى). أشكال فرعية أخرى، حيث يعرف السجلماسي ومنه كذلك (تجنيس السمع)، وهو "من قرب أحد فئل

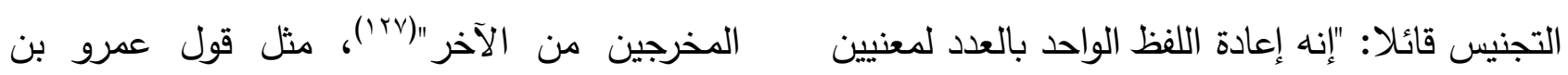

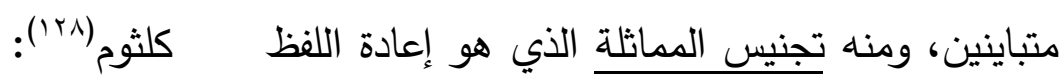
وقد علمت عليا كنانة أننا مطاعين في الهيجا،

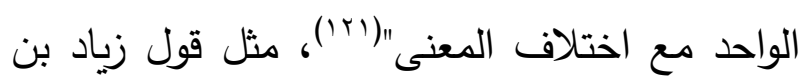
مطاعيم في المحل فتجنيس السمع في قوله: (مطاعين -مطاعيم) ومنه (تجنيس الخط)، وهو تحسين التصحيف، ومثاله قوله تعالى: "وهم يحسبون أنهم يحسنون

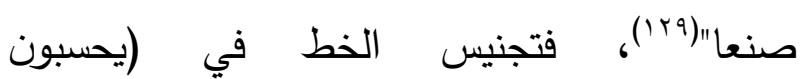
ويحسنون)('r.). وهكذا نلاحظ أن التجنيس يعد مكونا هاما من ونمن مكونات الشعرية لما له من ارتباط كبير بإثارة الخيال

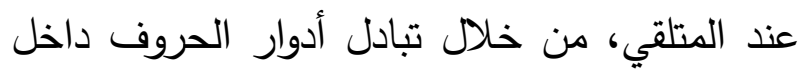

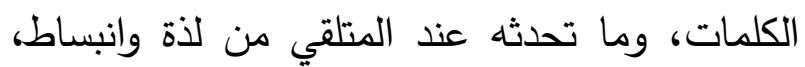

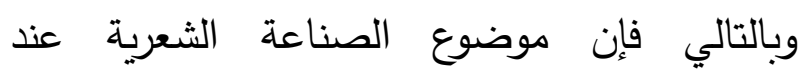
السجلماسي قد تركز أكثر ما تركز في جنس فئس التخييل، من خلال مكوناته الأربعة (التشبية والاستعارة والمماثلة (التمثيل) والمجاز) . كذلك نجد الثعرية أيضا في مثل تلك الأنواع البيانية، وإن كان السجلماسي قد وزعها على عدة الندان أنواع بيانية من بين أجناس كتابة العشرة، لكنها تلتقي

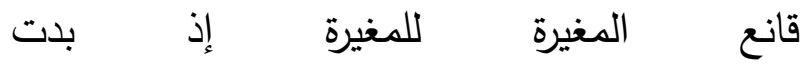

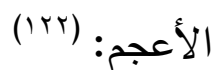
شعواء مشعلة كنبح النابح فهو يرثي المغيرة بن المهلب، فالأول اسمه،والثاني

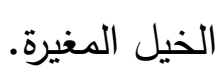
ومنه (تجنيس المضارعة) الذي يعرفه السجلماسي

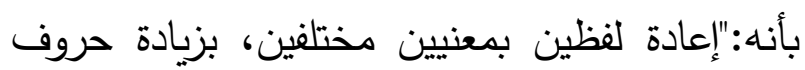

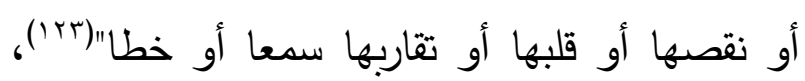
ومثل قوله تعالى:"وهم ينهون عنه وينأون عنه"(\{r) (1)، ونحن نلمس ما في ذلك من الجمال في تجنيس

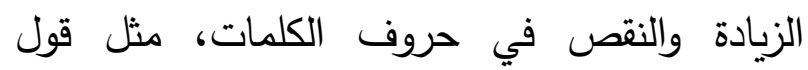

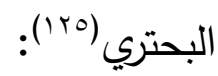

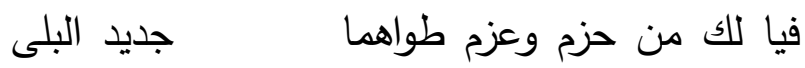
تحت الصفاء والصفائح فنلاحظ قوله (حزم وعزم)، وقوله (الصفا والصفائح)، وهو تجنيس المضارعة بزيادة حروف أو نقصها. 
هو الفعل، وهذا الفعل قد لا يكون مطابقا للحقيقة؛

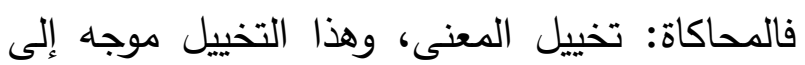

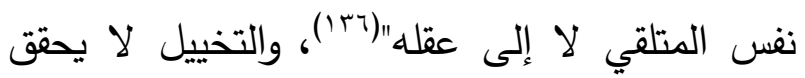
دوره تجاه المتلقي إلا من خلال الصورة الفنية، يقول حازم:"والتخييل أن تتمثل للسامع من لفظ الثناعر

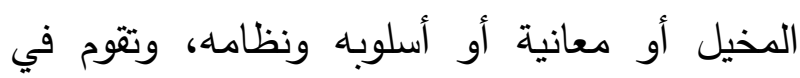
خياله صورة أو صور ينفعل لتخيلها وتصورها انفعالا من غير روية إلى جهة الانبساط أو الانقباض" (ITV)

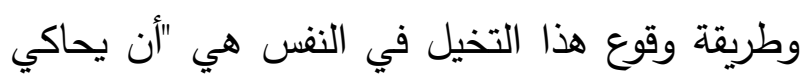
لها معنى بقول يخيله لها"( د"ا'). وعند المقارنة بين السجلماسي وحازم القرطاجني نجد أنهما "يلتقيان في تحديد مفهوم الثعر ، وهذا المفهوم الذي يجسد ملتقى الروافد الثقافية اليونانية والعربية،

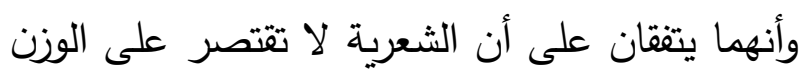
والقافية( و+1)، بالنسبة لوظيفة الشعر وبالتالي تأثيره

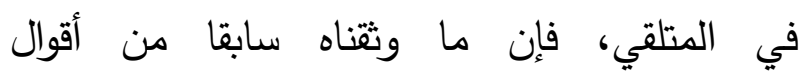
السجلماسي يؤكد أنه"يحصر وظيفة الشعر في التأثير على المتلقي، إما بتحقيق المتعة من خلال الثكل،

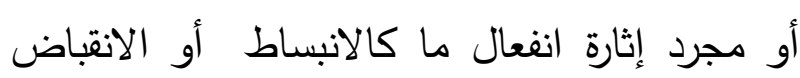
عن طريق التخييل، الذي يحدث لدى الدتلقي

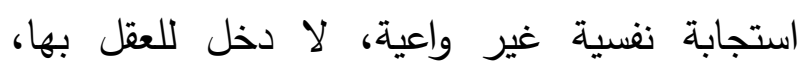
ومنشؤها الالتذاذ الناتج من إدراك العلاقات المتفاعلة

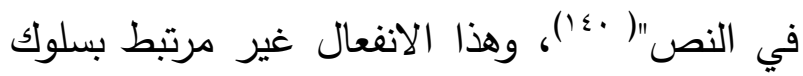
ما، مما يعني أن السجلماسي من أصحاب مقولة الخدئ

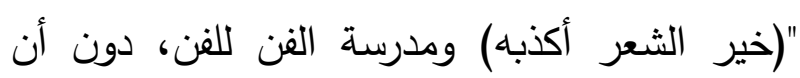

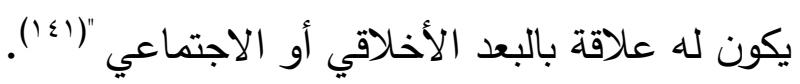

في اتصالها بمفهوم الثعر عند السجلماسي، ونرى أنها أركان داعمة لتثبيت البناء الثعري، وترسيخ لثفيع صفة الثعرية وما في الثعر من سحر وتحول داعل لثناء وإبداع. 7. مقاربة قصيرة بين السجلماسي وحازم القرطاجني:

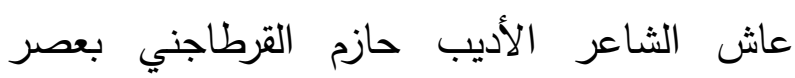
السجلماسي وتوفي قبله ( ع آح)، وهو من الأوائل في عصره الذين أفادوا البلاغة والنقد العربيين من وهن التهن خلا تفتحه على التفكير الأرسطي واليوناني،"وعني

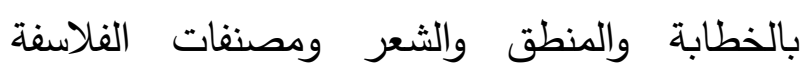
المسلمين كالفارابي وابن سينا، وله كتاب منهاج

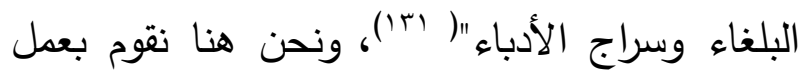
مقاربة ما بين السجلماسي وحازم فيما يخص الرؤية للشعر ، والنظرة للمتلقي، وما شابه ذلك من قضايا. يقول حازم في حقيقة الشعر:"إذ المعتبر في حقيقة

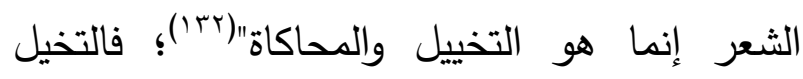
عنده أساس المعاني الشعرية، يقول:"إن التخيل هو قوام المعاني الشعرية، والإقناع هو قوام المعاني لنداني

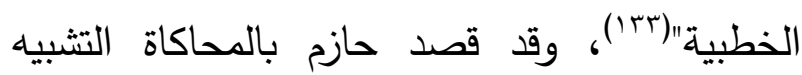
المرئي، وهي (المحاكاة) أساس الثعر وجوهره، وقد تكون ظاهرة أو متضمنة، ويعرف حازم الثعر

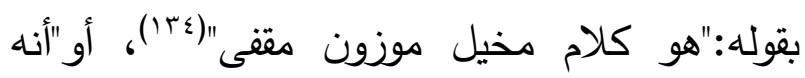
كلام مخيل مختص في لسان العرب بزيادة التقفية

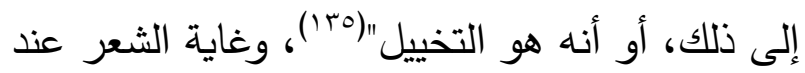
حازم هي"إحداث الأثر المرغوب في نفس المتلقي بوساطة التخييل، الذي هو وسيلة إلى غرض إحلى معين 
وهذا ما يختلف فيه السجلماسي عن حازم ما كان أكذب، لتحقيق اللذة والمتعة للنفس والمتلقي

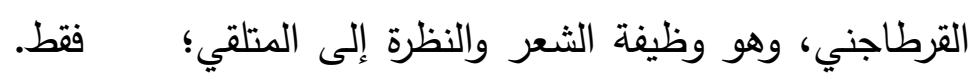

\section{الخاتمة}

ربما مع الصفحة الأخيرة من النوع الأخير من أنواع

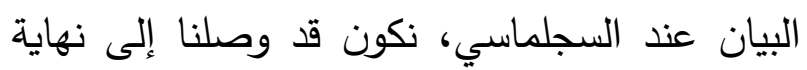

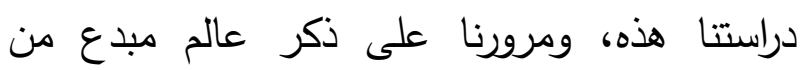
علماء العرب، من خلال تحفته الفلسفية والبلاغية فرونية والأدبية التي أطلق عليها اسم (المنزع البديع في تجنيس أساليب البديع)، حيث تبين من خلال هذا البحث الموجز أن السجلماسي رائد في مجال النقد والبلاغة والتتظير الأدبي، الناتج عن فكر وتعمق البق

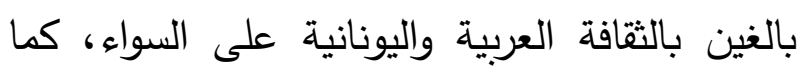
لاحظنا تقدمه في رؤيته للشعر ومكونات الشعرية، لئه

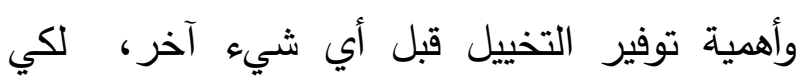
يكون الثعر كائنا حيا مكتملا ونابضا بالحركة.

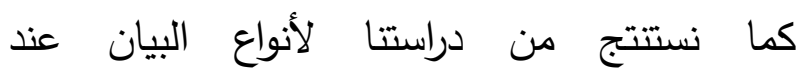
السجماسي، أنه رصد الكثير من الأركان الهامة

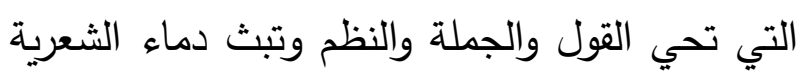
فيه، وبالتالي تخلق عند المتلقي اللذة والانفعال

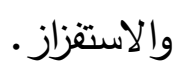

وإن كان الوقت المحدد لإعداد هذه الدراسة واقتصار بحثنا على جنس واحد من الأجناس التي بيناها وهو لإن التهان التخييل بصفته الركيزة الأساسية للصناعة الثعرية، الثناسل

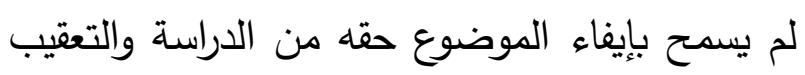
والتعليق كما يجب، إلا أننا نظن أن ما قلناه سواء في التخييل أو في باقي الأنواع البيانية، يعطينا

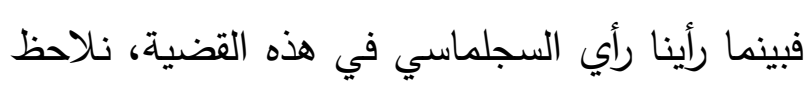
أن حازما قد أضاف إلى تعريفه للشعر دلالة واضحة

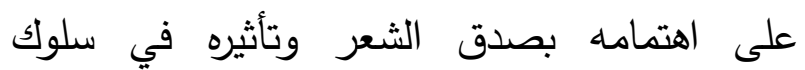
المتلقي، بالإضافة إلى تأثير الانفعال واللذة، يقول حازم:"الثعر كلام موزون مقفى من شأنه أن يحبب الإضي

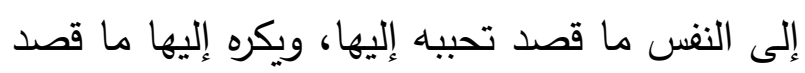
تكريها،، لتحمل بذلك على طلبه أو الهرب منها، بما يتضمن من حسن تخييل له، ومحاكاة مستقلة بنفسها أو متصورة بحسن هيأة تأليف الكلام، أو قوة صدقة،

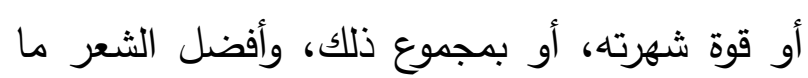
حسنت محاكاته وهيئته، وقويت شهرته أو صدقه، أو لون خفي كذبه، وقامت غرابته" ( rك (). وعن علاقة التخييل بالشعر وموقعه من نظرية

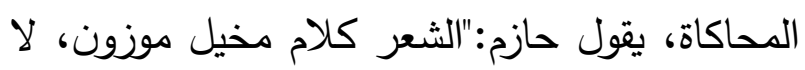

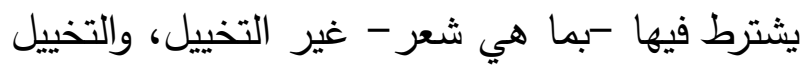

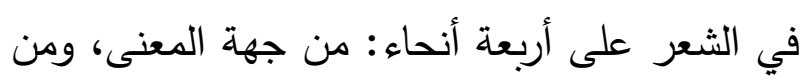
جهة الأسلوب، ومن جهة اللفظ، ومن جهة النظم النّاء

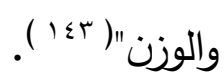

يتضح لنا من أقوال حازم السابقة، أنه من مؤيدي الفن للمتعة، والتأثير والفعل بوساطة التخييل، الذي ماني يكون دافعا لغرض معين هو الفعل، وبالتالي التغيير

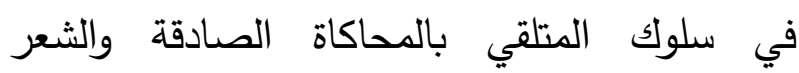
الأصدق، بينما كان السجلماسي يفضل من الثعر 
Y I.المصدر نفسه، ص ب . 1. 1. rا ا. انظر : المصدر نفسه، ص 0 . 1،7 • 1. ـ ا. المصدر نفسه، ص 1 . 1.

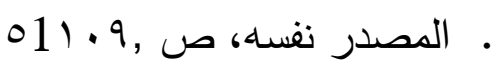

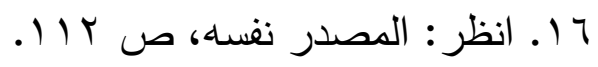
V1II , المصدر نفسه، ص .

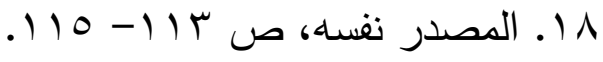
9 1. المصدر نفسه، ص r Y I I.

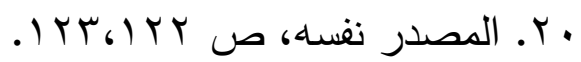

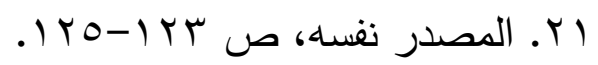

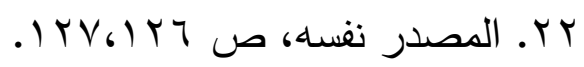

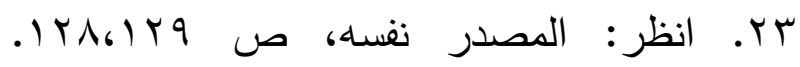
ع ז. القرآن الكريم، سورة الإسراء، آية آب. هץ. انظر: السجماسي، المنزع البديع، مصدر 117 ص سابق،

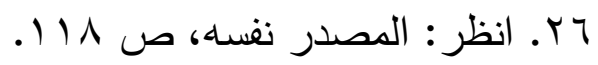

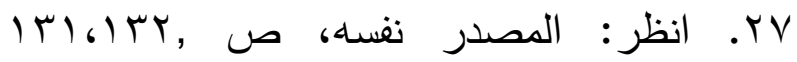

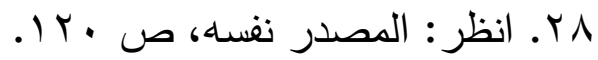

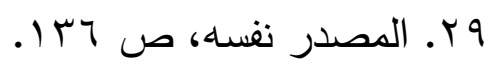

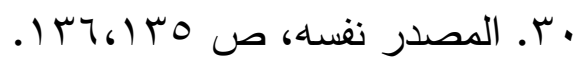
|".المصدر نفسه، ص بس إ. ץ". المصدر نفسه، ص דس

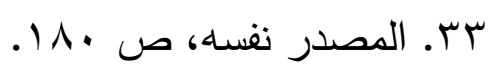

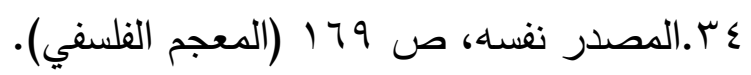
هم. المصدر نفسه، ص . •11. צr. المصدر نفسه، ص 1 آץ.
بعض الملامح الكافية لتكوين فكرة أو موقف من الكتاب ومؤلفه، ويسمح لنا بمحاولة إجراء المقارنة بين السجلماسي الموسوعي، وبين الذين سبقوه من علماء الأدب والنقد والبلاغة، ثم نكتشف إنه قد أبدع وأثرى الثقافة العربية بتلقيحها بنظيرتها اليونانية، من خلال استيعابه وتمكنه من علماء تلك الثقافة وفلاسفتها، وإسقاطه روحه الخلاقة والجديدة وبأسلوبه المتفرد على علوم اللغة العربية وآدابها . الهوامش

ا. انظر: السجماسي، أبو محمد القاسم، المنزع البديع في تجنيس أساليب البديع ، تحقيق علال

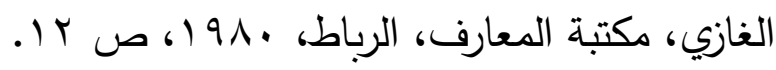

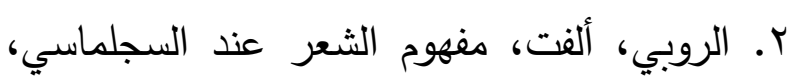

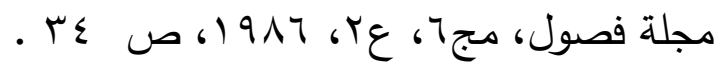
r. الروبي : مفهوم الشعر عند السجلماسي،

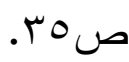
ع. انظر : السجلماسي، المنزع البديع، مصدر سابق، . ص ص ص 0. انظر : المصدر نفسه، ص 9؟ . 7. انظر : المصدر نغسد، ص .0Y-0.

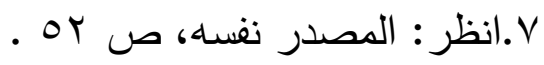
^.السجماسي، المنزع البديع، مصدر سابق، ص $.7 \cdot .69$ 9 9. المصدر نفسه : ص (17. . 1 . انظر : المصدر نفسه، ص 70.

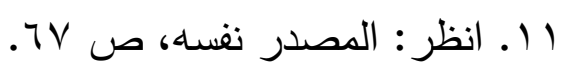


ror. الروبي، مفهوم الشعر عند السجماسي، مرجع ص, (1)

سابق، rه. الروبي، مفهوم الشعر عند السجماسي، مرجع

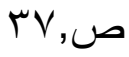
سابق، ؟ه. درابسة، الثعرية عن السجماسي، رجع ص, 11197 سابق، هـ. السجلماسي، المنزع البديع، مصدر سابق،

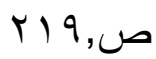

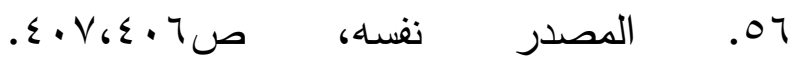
ص. ص, نفسـها،

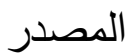
$.0 \mathrm{~V}$ هـ المصدر نفسه، ص برor.

9ه. السجماسي، المنزع البديع، مصدر سابق،

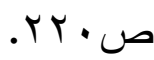
. 7. المصدر نفسه، ص. • r. ו7. المصدر نفسه، ص ابr. Y T. المصدر نفسه، ص آ آY.

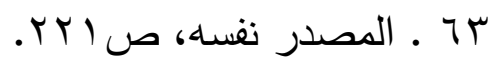

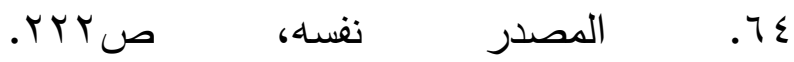
ه7. القرآن الكريم، سورة الرحمن، آية,؟؟

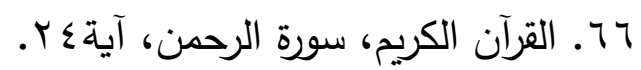

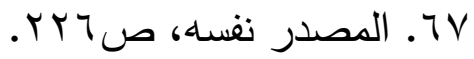

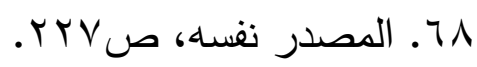

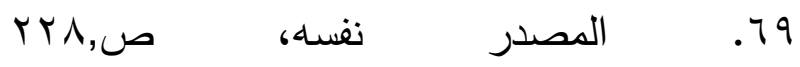

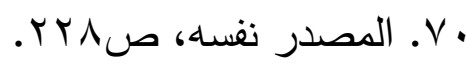
וV. المصدر نفسه، ص VY. VY المصدر نفسه، ص. rY. VV المصدر نفسه، ص V V. V. مبـ. درابسة، محمود، الشعرية عند السجلماسي في

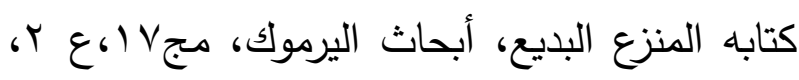
. IVA ص 61999 وس. الغازي، علال، تطور مصطلح التخييل في نظرية النقد الأدبي عند السجلماسي، مجلة كلية الآداب في جامعة فاس، عدد خاص رقم ؛ ؛

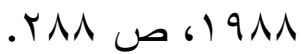
• ع. الغازي، علال، تطور مصطلح التخييل في نظرية النقد الأدبي عند السجلماسي، مرجع سابق،

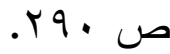
اءـ السجماسي، المنزع البديع، مصدر سابق، ص .$Y 1 \wedge$

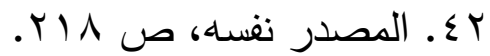

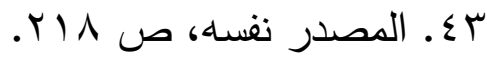

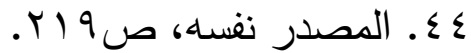
0ـ ـ الروبي، ألفت، مفهوم الشعر عند السجلماسي، مرجع سابق، ص ד بץ . Tء ـ السجماسي، المنزع البديع، مصدر سابق، ص .419

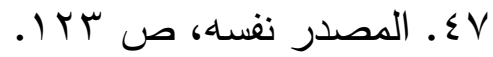

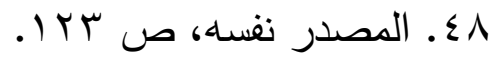

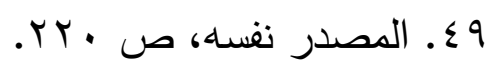

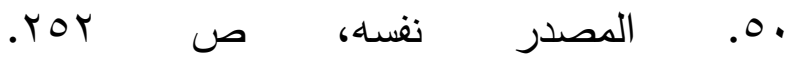
1. درابسة، الشعرية عن السجماسي، رجع

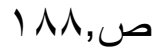
سابق، 
AV

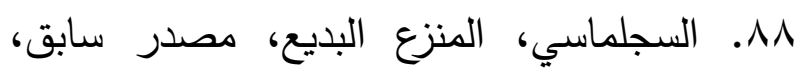

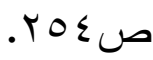
19. درابسة، محمود، الثعرية عند السجلماسي في

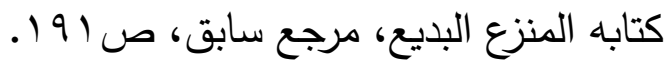

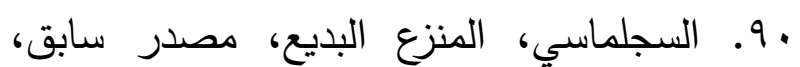

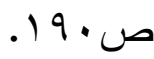

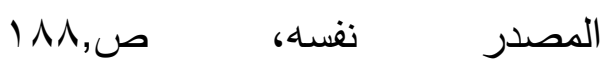
.91 rو. القرآن الكريم، سورة التكاثر ، آيةه،ج.

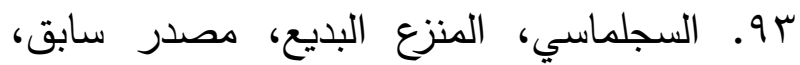

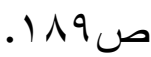

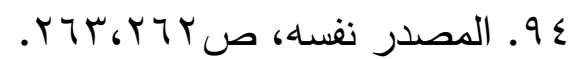
90. المصدر نفسه، صسז7 97.

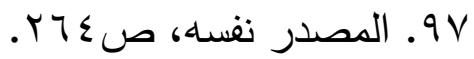

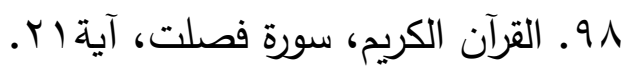
99 . انظر: السجلماسي، المنزع البديع، مصدر لـورة

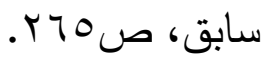

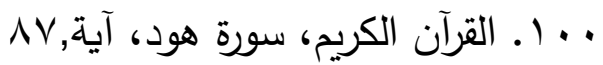

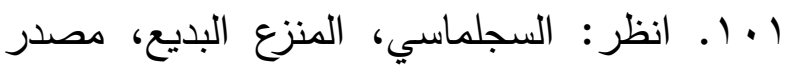

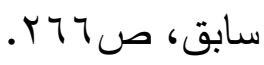

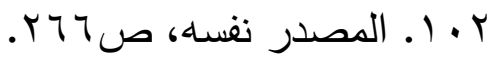
ץ • ( • درابسة، محمود، الشعرية عند السجلماسي في

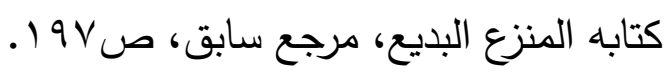

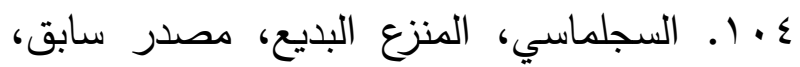

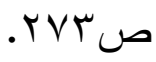

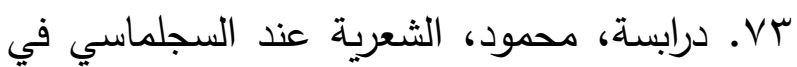

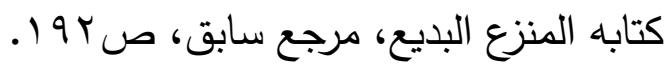

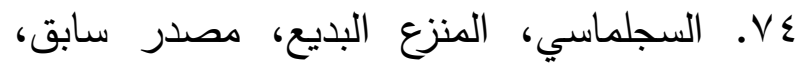

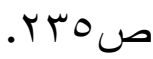

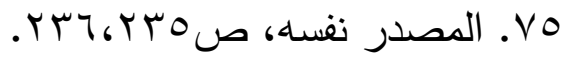
TV. المتنبي، أبو الطيب: الديوان، تحقيق عبد الرحمن البرقوقي، دار الكتاب العربي، بيروت، ط؟، מ. السجلماسي، المنزع البديع، مصدر سابق،

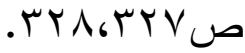
VA الروبي، مفهوم الشعر عند السجلماسي، مرجع

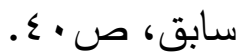
v9. السجلماسي، المنزع البديع، مصدر سابق، ( ) ص • ^. درابسة، محمود، الشعرية عند السجلماسي في

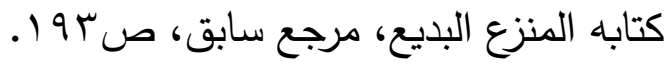

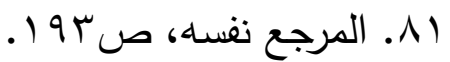

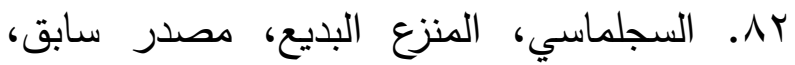
ص ص זم. القرآن الكريم، سورة المدثر، آية؛ء.

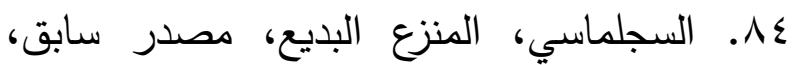

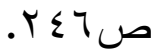
10. المصدر نفسه، صرمبr. ror.

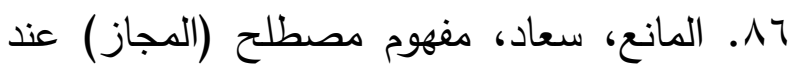
السجلماسي في علاقته بمصطلح (التخييل)، أبحاث

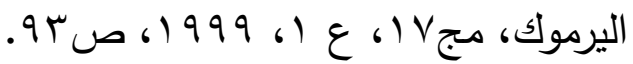


سץ ا ـ المصدر نفسه، ص ع 1. الترآن الكريم، سورة الأنعام، آيةجr. هץ ا. انظر: السجماسي، المنزع البديع، مصدر

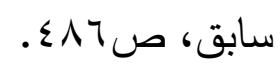

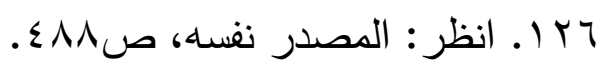

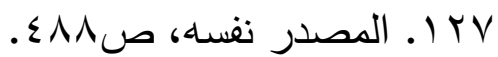

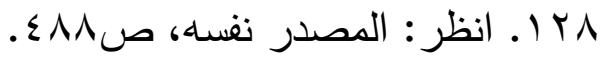

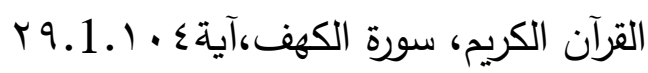
• rا. السجماسي، المنزع البديع، مصدر سابق،

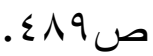
اץ| ـ المصدر نفسه، صسا س. ץ"ا. القرطاجني، حازم، منهاج البلغاء وسراج الأدباء، تحقيق محمد الحبيب ابن الخوجة، دار

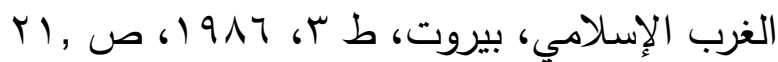
س" ا ـ المرجع نفسه، ص آ آس. ع ا ـ المرجع نفسه، ص ا. (V) هץا. المرجع نفسه، ص 9^^، وانظر: الروبي، مفهوم الشعر عند السجلماسي، مرجع سابق، ص rV דس (.درابسة، محمود، الشعرية عند السجلماسي في كتابه المنزع البديع، مرجع سابق، ص ، 1 1. V I . القرطاجني، حازم، منهاج البلغاء، مرجع

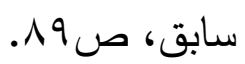

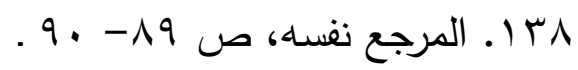
و با ـ درابسة، محمود، الشعرية عند السجلماسي في كتابه المنزع البديع، مرجع سابق، ص I I ل .
ه 1 . انظر: السجماسي، المنزع البديع، مصدر

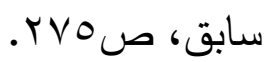

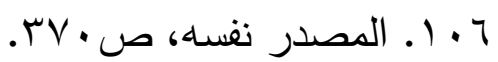
V. I. المصدر نفسه، صـوس. A • ا ـ المصدر نفسه، صوVq.

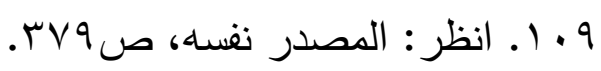

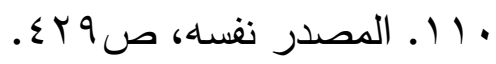
111 . . المصدر نغسه، ص اسبح.

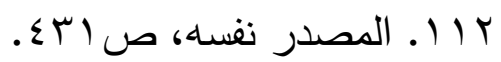

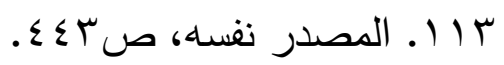
ع ا1 ـ القرآن الكريخ، سورة فاطر ، آية9. 10 ا ـ درابسة، محمود، الشعرية عند السجلماسي في كتابه المنزع البديع، مرجع سابق، ص19 ا. 71 1 . السجلماسي، المنزع البديع، مصدر سابق،

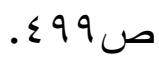
وانظر للنوسع: الجرجاني، الرماني الخطابي، النكت في إعجاز القرآن، دار المعارف، مصر، طس، $.19 \vee 7$

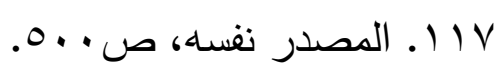
11 1. درابسة، محمود، الشعرية عند السجلماسي في كتابه المنزع البديع، مرجع سابق، ص99 1 ـ . 9 11 ــ السجماسي، المنزع البديع، مصدر سابق،

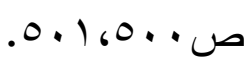
• Y ا ـ انظر : المصدر نفسه، صع . .0.

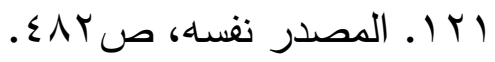

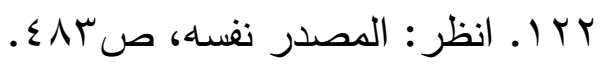


ه.السجماسي، أبو محمد القاسم:المنزع البديع في تجنيس أساليب البديع، تحقيق علاء الغازي، مكتبة

المعارف، الرباط، ، 919 T. الغازي، علال: تطور مصطلح التخييل في نظربة النقد الأدبي عند السجلماسي، مجلة كلية الآداب في جامعة فاس، عدد خاص، رقم ع، $.19 \wedge 1$ V. القرطاجني، حازم: منهاج البلغاء وسراج الأدباء، تحقيق محمد الحبيب ابن الخوجة، دار الغرب الإسلامي، بيروت، طس، 1917 1. ^. المانع، سعاد: مفهوم مصطلح (المجاز) عند السجماسي في علاقته بمصطلح (التخييل)، أبحاث اليرموك، مجل ال، ع (6 1999.

9. المتنبي، أبو الطيب: الديوان، تحقيق عبد الرحمن البرقوقي، دار الكتاب العربي، بيروت، ط ب، ج)

.191 .
• ـ ا. الروبي، مفهوم الشعر عند السجماسي، مرجع سابق، ص هوب. اء ا ـ درابسة، محمود، الشعرية عند السجلماسي في

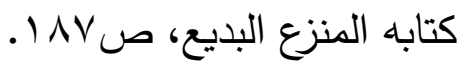
r ا . القرطاجني، حازم، منهاج البلغاء، مرجع

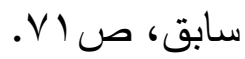
بـ ا ـ المرجع نفسـ، ص ص 9. المـــــــــ

المصادر والمراحع:

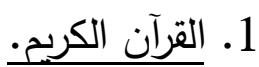
r. الجرجاني، الرماني الخطابي، النكت في إعجاز

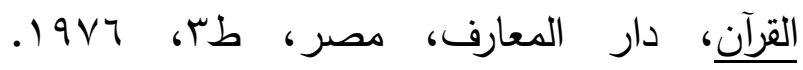
r. درابسة، محمود: الشعربة عند السجلماسي في كتابه ( المنزع البديع )، أبحاث اليرموك، مج له $\left..19996 \varepsilon^{6}\right) \mathrm{V}$ ع. الروبي، ألفت:مفهوم الشعر عند السجلماسي،

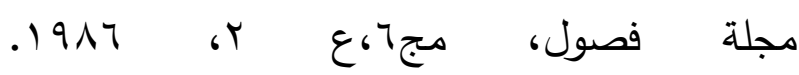




\title{
The location of the visualization at the Diamond Record
}

\author{
Dr. Enas Mahmoud Abdullah Abu Salem \\ Professor of Literature and Assistant Modern Criticism \\ Department of Arabic Language - College of Humanities \\ King Khalid University
}

\begin{abstract}
Muhammad al-Sijlmassi, who lived in Morocco in the late seventh Hijri century (7 AH), considered as one of the greatest pioneers Moroccan rhetorical school ,he was creative as he wrote his book tagged (The adorable Inclination in gendering methods of prose) In AH 704 / AD 1304.

(The adorable Inclination) 'is an innovative and serious book in criticism and rhetoric from a philosophical and logical point of view, in which Al Sijilmassi employed the mind, taste and culture between Arabic and Greek in the critical and rhetorical lesson, and came up with a new approach that is more understanding of Aristotelian theories in criticism and rhetoric.

The aim of this study was to show the distinctive features of the book of the Inclination through a review of the most important of the topics classified by Al Sijlmassi under the science of the rhetoric - especially mentioning those related to poetry and capillarity and the main elements that Al Sijlmassi sees are the real components the capillarity of poetry and art and it's beauty, where this was a reality In a type of (imagination) more than all other types, and therefore our study came to the gender of imagination more detailed and broaden than the rest of the genders of the book; because imagination is the subject of poetic formation, and this is field of our study.

We did not forget to also observe any other species that may be a catalyst in the formation of poetry, occurred in a section other than the section of imagination, so the methodology of this study began with a quick view of the era of Al Sijlmassi and a brief on his biography, and his thought about the development of rhetoric in his time.

Then we presented in the second section some of the features of the book and the new of Al Sijlmassi, which distinguish him, before we get to the third section, as soon as we enter it we get in his world and we begin our tour in it and what he inundates about the subject of imagination, which is our main subject of this study.

It was found through the brief research that $\mathrm{Al} \mathrm{Sijlmassi}$ is a pioneer in the field of criticism, rhetoric and literary theorem, resulted from the deep thought and deepening of the culture of both Arabic and Greek, as we have seen his progress in his vision of poetry and capillarity components, and the importance of providing imagination before anything else, so that poetry to be a Complete and vibrant living being.

As we conclude from our study of the types of rhetoric Al Sijlmassi has, he monitored a lot of important pillars that revives the words and sentences and versification and transmit poetic blood in it, and thus create to the recipient pleasure, emotion and provocation.

Finally, we hope that we have succeeded as much as our humble effort in going through a giant book!
\end{abstract}

